\title{
LOS DERECHOS AL HONOR, A LA INTIMIDAD Y A LA PROPIA IMAGEN EN LAS REDES SOCIALES: LA DIFUSIÓN NO CONSENTIDA DE IMÁGENES*
}

\author{
Lucía Gil VALLILENGUA \\ GRADUADA EN DERECHO \\ MÁSTER DE ACCESO A LA ABOGACÍA \\ UNIVERSIDAD DE LA RIOJA
}

SUMARIO: I. Introducción. II. Las redes sociales como un nuevo espacio para la vulneración de los derechos de personalidad. III. Los derechos del artículo i8 afectados. III.I. El derecho a la propia imagen. III.2. El derecho a la intimidad. III.3. El derecho al honor. III.4. El derecho a la protección de datos. IV. Análisis de los derechos del artículo 20. VI. El consentimiento como elemento esencial. VI. Excepciones a la regla general del consentimiento. VI.I. Excepciones por razones objetivas. VI.2. Excepciones por razones subjetivas. VI.2.I. Personas anónimas y captación «meramente accesoria». VI.2.2. Personajes públicos. VI.2.3. Personas fallecidas. VI.2.4. Menores. VI.2.5. Personas jurídicas. VII. Conclusiones.

RESUMEN: En un momento en el que los términos Web 2.0 y «redes sociales» forman parte de nuestro día a día, se hace necesario un acercamiento jurídico riguroso a la nueva realidad que se nos presenta. En este sentido, el presente artículo pretende abordar, desde una perspectiva práctica, uno de los numerosos problemas que suscita la presencia de redes sociales en el tejido de las relaciones culturales y sociales que configuran la vida cotidiana de la sociedad del siglo XXI. Concretamente, las intromisiones ilegítimas que se producen a consecuencia de la difusión en las redes sociales de imágenes o vídeos sin consentimiento. La amplitud temática y el enfoque desde el que se aborda implica analizar los fundamentos constitucionales clásicos desde una perspectiva renovada para determinar cuándo, en este contexto, existe lesión de los fundamentales al honor, la intimidad y la propia imagen.

Palabras Clave: redes sociales, derecho al honor, derecho a la intimidad, derecho a la propia imagen, derecho a la protección de datos

ABSTRACT: In a time when Web 2.0 and social networking terms are part of our daily lives, it is necessary and strict legal approach to the new reality. Therefore, the present research work looks into one of the many problems caused social networks in cultural and social relations that shape the everyday of the XXI century. Specifically, the rights injury produced as a result of the diffusion in social networks images or videos without consent. The breath of the subject and the focus from it is approached from the constitutional involves analyzing the classical constitutional foundations from a renewed perspective to determine when, in thin context, there is an injury of the rights to honor privacy and self-image.

KEYWORDS: social networks, right to honor, right to privacy, right to self-image, data protection

\footnotetext{
"Extracto del Trabajo Fin de Máster de Acceso a la Abogacía «Protección del Honor, Intimidad, Propia Imagen y Datos Personales en las redes sociales: la difusión no consentida de imágenes».
} 


\section{Introducción}

Cuando el astronauta del Apolo, Neil Armstrong, pisó por primera vez la luna dijo: «Un pequeño paso para el hombre, un enorme salto para la humanidad». Ese día, los $384.440 \mathrm{~km}$ que separan a la Tierra de nuestro satélite comenzaron a parecer menos. Desde entonces, el hombre no ha dejado de acortar distancias y, hoy, casi cinco décadas más tarde, con una superficie de $510.072 .000 \mathrm{~km}$ y una población de 7,I25 miles de millones, el planeta Tierra nunca ha sido tan pequeño.

Esta vez, no es un «pequeño paso», sino un pequeño «click» el que ha revolucionado nuestros horizontes, porque no es el espacio exterior sino el «ciberespacio» el que ha trastocado las variables espacio-tiempo. Ahora la lejanía se convierte en inmediatez, nuestros pensamientos pueden dar la vuelta al mundo en tan sólo un segundo y las grandes culpables son: las redes sociales.

El «big bang» de este universo se remonta a 1995, cuando Randy Conrads creara un sitio web (Classmates), con el que pretendía que se pudiera recuperar el contacto con antiguos compañeros de colegio o universidad ${ }^{2}$.

Basadas en la «Teoría de los seis grados» ${ }^{3}$ y en la trasmutación de Internet a la Web 2.0, las redes sociales han experimentado un extraordinario crecimiento popular ${ }^{4}$. España ha aumentado su «población online» y más de catorce millones de personas utilizan activamente las redes sociales. Ello unido a las múltiples posibilidades de reproducir, intercambiar y almacenar datos, sonidos e imágenes ha generado un escenario idóneo para la vulneración de los derechos al honor, la intimidad y la propia imagen, propiciando que los efectos y las consecuencias de estas vulneraciones se multipliquen, se difundan más ampliamente y permanezcan en el tiempo5.

En este contexto, la difusión de imágenes y vídeos sin consentimiento a través de las redes sociales se ha convertido en un tema tan usual como desafiante desde la perspectiva

IREINHART KosSELleck, es uno de los autores que más ha desarrollado esta noción considerando que la acelaración es el rasgo más llamativo de la modernidad. REINHART KosseLLECK, Aceleración, prognosis $y$ secularización, Pre-Textos, Valencia, 2003.

${ }^{2}$ Posteriormente, nacen otras como SixDegress en 1997, MySpace, Hi5, Secondlife y Xing, en 2003, Facebook en 2004, Twitter y Tuenti en 2006. Datos sacados de

http://recursostic.educacion.es/observatorio/web/es/internet/web-20/I043-redes-sociales?showall=I (fecha de consulta: I7/II/20I5).

${ }^{3}$ Planteada por el húngaro FrigYes KARINTHY en I929, partía de un pequeño número de contactos según el cual se puede ir construyendo una cadena de crecimiento exponencial que puede llegar a unir a la humanidad entera. FRIGYES KARINTHY «Chain-Links», I929, Everything in Different. Translated from Hungarian and annoted by Adam Makkai, edited by Enikö Jankó.

${ }^{4}$ El 82\% de los internautas de entre I8-55 años utilizan redes sociales, lo que representa más de I4 millones de usuario en nuestro país. Facebook (96\%) sigue siendo la red social por excelencia, seguida de Youtube (66\%) y Twitter (56\%). Facebook sigue siendo la red social con mayor frecuencia de utilización (a diario) seguida de Twitter. Datos extraídos del Informe de 30 de octubre de 2014 del Observatorio de Redes Sociales -VI Ola, disponible en boletines.prisadigital.com/viobservatoriorrss.pdf (fecha de consulta: I7/II/20I5).

${ }^{5}$ Una de las actividades más frecuentes en el uso de las redes sociales es la de publicar contenidos (39\%) Informe de IAB de enero de 20I5, disponible en www.iabspain.net (fecha de consulta I5/II/20I5). 
jurídica ${ }^{6}$. Tanto es así que a día de hoy no existe un corpus doctrinal y jurisprudencial al efecto, sino aislados pronunciamientos jurisprudenciales, en buena parte contradictorios. Es precisamente esta virtualidad práctica y el reto que plantea frente a un ordenamiento jurídico ajeno a este nuevo mundo virtual, lo que me llevó a abordar el presente estudio.

Con estas premisas, en las siguientes líneas se pretende aportar al lector una visión global y completa pero, sobre todo, eminentemente práctica, en sintonía con mi formación como abogada y las características de la profesión.

Para ello, se abordará un estudio dedicado a establecer los parámetros jurídicos para determinar la existencia de lesión, en una aproximación constitucional a los derechos fundamentales en conflicto.

\section{Las redes sociales como nuevo espacio para la vulneración de los derechos de perso- nalidad}

«Votaremos favorablemente todo lo que signifique incluir limitaciones de la informática en la Constitución» ${ }^{7}$. Este era el clima que se respiraba en las Cortes de I978, cuando nuestro constituyente decidiera incluir el apartado cuarto del art. i8 de la Constitución que, en su vaga y confusa redacción, ya mostraba el recelo a la informática ${ }^{8}$. Ciertamente, en Estados Unidos y en Europa, en la década de los años setenta, se había despertado esta desconfianza. Sin embargo, el texto final acabaría separándose de la estela europea, limitada a la protección de la intimidad, ampliando las garantías constitucionales al resto de derechos ${ }^{9}$.

En verdad, el constituyente no andaba nada desencaminado. Hoy, la informática, y, en concreto, las redes sociales son un espacio inagotable de vulneración de los derechos de la personalidad ${ }^{10}$. Y la difusión no consentida de imágenes o vídeos a través de las redes sociales no es una excepción.

\footnotetext{
${ }^{6}$ Los datos estadísticos acerca de los hechos delictivos incluidos en la Instrucción 2/20II de la Fiscalía General, sobre el Fiscal de Sala de Criminalidad Informática y las secciones de criminalidad informática de las Fiscalías, revelan que en el año 20I4, llegaron a conocimiento del Ministerio Fiscal un total de 20.534 procedimientos judiciales por este tipo de ilícitos, lo que supone un incremento en un 71,21\% respecto de los II.990 procedimientos registrados en el año 2013 y en más de un 210\% respecto de los 6.532 identificados en 20II. En concreto, los procedimientos por delitos de descubrimiento y revelación de secretos ascienden un 4,I7\%. Memoria 2015 de la Fiscal General del Estado, disponible en

https://www.fiscal.es/memorias/memoria20I5/FISCALIA.../MEMFISI5.pdf (fecha de consulta I5/II/20I5).

${ }^{7}$ Intervención del señor RoCA JUNYENT, en D.S.C., de i9 de mayo de i978, núm 70, pág. 2529.

${ }^{8}$ El art. I8.4 de la Constitución Española establece que «La ley limitará el uso de la informática para garantizar el honor y la intimidad personal y familiar de los ciudadanos y el pleno ejercicio de sus derechos».

${ }^{9}$ Tesis que se corresponde las enmiendas presentadas por el Grupo Mixto y por Minoría Catalana que alcanzó el voto unánime de la Comisión Constitucional del Congreso. Sin embargo, se ha señalado que, al incluir su regulación como un apéndice del artículo I8, dedicado al reconocimiento al derecho a la intimidad, puede dar pie a opciones hermenéuticas que dificulten la extensión de su tutela a los demás derechos y libertades fundamentales. A este respecto, ver PÉREZ LUÑo A.E., «Informática y libertad. Comentario al artículo I8.4 de la Constitución Española», Revista de Estudios Políticos, N²4, I98I, págs. 3I- 53.

${ }^{10}$ FernÁndez Esteban, M.L., «El impacto de las nuevas tecnologías e Internet en los derechos del art. i8 de la Constitución», Anuario de la Facultad de Derecho, pág. 528.
} 
Dada la naturaleza de la cuestión, el estudio del tema requiere un previo examen de los derechos fundamentales involucrados, en el que el eje de análisis se ha de centrar en la pugna entre el derecho al honor, la intimidad y la propia imagen frente a la libertad de información y expresión. Pugna que, a menudo, se traslada en la práctica jurídica a los argumentos de las partes de los procedimientos jurisdiccionales a los que dan causa.

Hemos de anticipar al lector que se trata de un viejo conflicto, sí, pero con la peculiaridad de que se libra en un nuevo escenario haciendo que asistamos, entre otras cosas, a algo tan insólito en el recuerdo constitucional como el nacimiento de un nuevo derecho fundamental, al tiempo de la necesaria adaptación de otros, lo que hace que el tema torne, si cabe, más interesante.

\section{Los derechos del artículo I8 afectados}

Centrémonos primero en los derechos del art. I8 de la Constitución. Sin entrar en disquisiciones más estrictas que las que este trabajo exige, sí debemos señalar que el derecho al honor, la intimidad y la propia imagen están, a salvo de su reconocida autonomía $^{\mathrm{II}}$, estrechamente relacionados ${ }^{\mathrm{I2}}$. Ello supone que la difusión de una imagen en las redes sociales pueda producir la lesión, simultánea o no, del derecho a la imagen con el derecho a la intimidad y/o el derecho al honor ${ }^{\mathrm{r} 3}$.

III.I. El derecho a la propia imagen

El derecho a la propia imagen es un derecho relativamente reciente, incorporado con cierta originalidad en nuestra Carta Magna y escasamente abordado hasta hace poco en la jurisprudencia del Tribunal Constitucional que, en numerosas ocasiones, lo ha confundido con sus colegislados derechos ${ }^{\mathrm{I}}$.

Si examinamos la jurisprudencia constitucional ${ }^{15}$, el derecho a la propia imagen atribuye a su titular la facultad de disponer de la representación de su aspecto físico siempre que permita su identificación, lo que conlleva el derecho a determinar la información

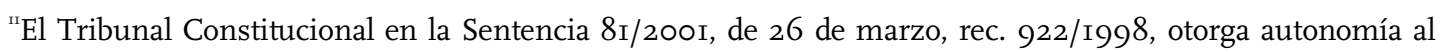
derecho fundamental a la propia imagen, determinando que cada uno de los derechos fundamentales tienen su propia sustantividad, por lo que la vulneración de uno de ellos no conlleva necesariamente la de los demás.

${ }^{12}$ El denominador común de la protección de los citados derechos fundamentales es la dignidad y la libertad del individuo frente a la acción y conocimiento de los demás, que conlleva una autodeterminación sobre uno mismo. Cfr. SÁnChez LAFUente, F., «El derecho a la intimidad ante la difusión inconsentida de imágenes facilitadas por el propio titular», Actualidad Civil, no 9, 2015, págs.894-906, disponible en laleydigital.laley.es (fecha de consulta I7/II/20I5).

${ }^{13}$ Siguiendo el criterio de la doctrina autonomista, cabe aclarar que no necesariamente dicha lesión va unida en todos los casos, dado que la protección otorgada a la imagen no requiere la concurrencia de hechos dañosos de otros derechos personalísimos.

${ }^{14}$ Así por ejemplo, en la STS del Caso Cortina, de 2I de octubre de I997, rec.I827/1993, se puede ver como el Tribunal, en un momento de la argumentación mezcla los dos derechos.

${ }^{15} \mathrm{Cfr}$. SSTC I2/2012 de 30 de enero, rec. 4821/2009, I76/2013 de 21 de octubre, rec. I782/2010 o 208/2013 de i6 de diciembre, rec. IIо/20II.
} 
gráfica generada por los rasgos físicos que le hagan recognoscible, que pueda ser captada o tener difusión pública. Lo que no implica necesariamente que la representación sea facial. Y así se ha considerado que afecta a la propia imagen la publicación de la silueta de un médico ${ }^{\mathrm{I}}$. Sin embargo, sin caer en el error común de confundir la vertiente patrimonial con la fundamental o personal del derecho a la imagen, sí que ha de referirse necesariamente a una parte corporal. Recordemos a este respecto el conocido Caso Emilio Aragón en el que, efectivamente, se evocaba a un personaje de ficción creado por él, tratándose simplemente de una cuestión de explotación comercial ${ }^{\text {17}}$. En la misma vertiente patrimonial, se encuentra la utilización de dobles de personas famosas para usos publicitarios ${ }^{18}$.

Este derecho ha de conllevar, por tanto, derecho a impedir la obtención, reproducción o publicación de su propia imagen por un tercero no autorizado ${ }^{\text {19. }}$. Podemos extraer, por tanto, que las intromisiones relativas al derecho a la imagen abarcan varios actos distintos: por un lado, la captación u obtención y por otro la reproducción o publicación de la imagen ${ }^{20}$. De modo que «el bien constitucionalmente protegido no es tanto la mera reproducción gráfica de cualquier elemento corporal del individuo como la evocación social de la persona que habitualmente se plasma a través de aquélla» ${ }^{2 \mathrm{I}}$.

Sobra decir, en este sentido, que el derecho a la propia imagen tiene la misma naturaleza en el mundo 2.0 que en el mundo off-line. Por ello, advertimos que siempre que el consentimiento no sea necesario y la imagen difundida muestre rasgos físicos que permitan la identificación de una persona que no lo ha autorizado, se estará conculcando el derecho a la propia imagen. Cuando además, afecte al ámbito íntimo de la persona, se estará afectando conjuntamente a otro de los derechos fundamentales del art. I8: la intimidad personal y familiar ${ }^{22}$.

\footnotetext{
${ }^{16}$ En la STS 752/I988, de I8 de julio, rec. I319/I994, se reconoce el derecho a la propia imagen de un médico infectado con el virus del SIDA, y cuya silueta fotografiada a contraluz, pero identificable, fue difundida en una publicación.

${ }^{17}$ Resuelto en la ya mencionada STC 8I/200I, de 26 de marzo, rec. 922/1998. El supuesto de hecho tiene su raíz en un anuncio publicitario de la empresa Proborín, aparecido en diversos medios de comunicación en los que, evitando reproducir el nombre y la imagen de Emilio Aragón, se utilizaban una serie de expresiones y representaciones gráficas, consistentes en un dibujo de unas piernas cruzadas, vistiendo unos pantalones negros y calzando unas botas deportivas de color blanco, conjuntamente con una leyenda que decía: «la persona más popular de España está dejando de decir: te huelen los pies».

${ }^{18}$ Caso Jacqueline Onassis c. Christian Dior de II de junio de I984, disponible en www.makoesler.com (fecha de consulta. A nivel nacional, destaca la Sentencia de la Audiencia de Barcelona de 28 de junio de 2002 , rec. 7IO/200I, en la que se condena a una empresa de lácteos a indemnizar al bailarín Joaquín Cortés por utilizar en un anuncio publicitario a un joven bailando flamenco, con el torso desnudo, vistiendo pantalones oscuros y de cabello largo y negro, tal y como es la imagen que caracteriza al famoso.

${ }^{19}$ Así lo expone la STC 196/2004, de I5 de noviembre, rec. 1322/2000, en su FJ $2^{\circ}$.

${ }^{20}$ La STS 5I8/20I2, de 24 de julio de 20I2, rec. 280/20IO, en FJ6 ${ }^{\circ}$ lo define como «un derecho de la personalidad, derivado de la dignidad humana y dirigido a proteger la dimensión moral de las personas, que atribuye a su titular un derecho a determinar la información gráfica generada por sus rasgos físicos personales que pueden tener difusión pública y a impedir la obtención, reproducción o publicación de la imagen por parte de un tercero no autorizado, sea cual sea la finalidad -informativa, comercial, científica, cultural, etc.perseguida por quien la capta». También 7.5 y 7.6 LO I/1982.
}

${ }^{21}$ Cfr. STC 23/20io de 27 de abril, rec. 4239/2006.

${ }^{22}$ En el Caso Alcócer, STC 83/2002, de 22 de abril, rec. I82/98, FJ 5, el Tribunal Constitucional aclara que la difusión de una imagen vulnerará al mismo tiempo el derecho a la propia imagen y la intimidad cuando, 


\section{III.2. El derecho a la intimidad}

El derecho a la intimidad implica la existencia de un ámbito propio y reservado frente a la acción y el conocimiento de los demás, necesario, según las pautas de nuestra cultura para mantener una calidad mínima de vida humana ${ }^{23}$. Sin embargo, no se nos puede pasar inadvertido que somos los individuos quienes definimos, expresa o implícitamente, cuál es nuestra esfera privada y qué difusión le damos a la información relativa a la misma ${ }^{24}$. Y tampoco podemos obviar que una de las actividades más frecuentes en las redes sociales en Internet (en adelante, RSI) consiste en publicar fotos personales y familiares. Por eso, ¿podemos hablar de intimidad en las RSI? Pues bien, aunque pueda parecer contradictorio la respuesta es afirmativa. Las revelaciones hechas en un determinado contexto no legitiman a su difusión a otros o la imagen captada en lugares públicos sólo podrá reproducirse si la ampara su carácter «noticiable» ${ }^{25}$. Y ello aunque la persona afectada haya difundido concretos aspectos de su vida privada, porque sólo aquéllos que expresa y voluntariamente haya difundido pueden ser objeto de divulgación ${ }^{26}$.

Habida cuenta de lo hasta aquí dicho, llegamos a un marco mucho más complejo. En primer término, podemos decir que cabe, pues, la vulneración exclusiva del derecho a la intimidad en los casos en los que mediante las imágenes se invada el espacio íntimo de la persona, pero la persona afectada no resulte recognoscible. Por ello, los tribunales han declarado, entre otros extremos, que el hecho de que la imagen muestre el cuerpo desnudo podría no ser relevante a efectos de apreciar la existencia de intromisión en el derecho a la propia imagen, en tanto este derecho lo que impide es la obtención, reproducción o publicación por un tercero no autorizado de una imagen que contenga los rasgos físicos de una persona que permita reconocer su identidad $\mathrm{d}^{27}$. En otras ocasiones, puede vulnerarse el derecho a la propia imagen sin conculcar el derecho a la intimidad, supuesto éste que se

además de mostrar los rasgos físicos que permiten la identificación de una persona determinada, revele aspectos de su vida privada o familiar que se hayan quedo reservar al público.

Pero, ciertamente, ambos derechos comparten una misma estructura jurídica de facultad de exclusión o libertad negativa. Cfr. De LA Iglesia ChAMARRo, I., «Las redes sociales digitales: ¿hacia una nueva configuración de los derecho fundamentales en Internet», Revista española de Derecho Constitucional, № 67, 2003, págs. 296.

${ }^{23}$ Contreras Navidad, S., La Protección del Honor, la Intimidad y la Propia Imagen en Internet, Navarra, Aranzadi, 20I2, pág. 2I.

${ }^{24}$ Los derechos de la personalidad, además de por el momento social, están determinados de manera decisiva por «el propio concepto que cada persona según sus actos propios mantenga al respecto y determine sus pautas de comportamiento. Así lo expresa la Exposición de Motivos de la LO ı/ı982, de 5 de mayo, de protección civil del derecho al honor, a la intimidad personal y familiar y a la propia imagen.

${ }^{25}$ Rico CARrillo, M., «El derecho al honor, intimidad e imagen y la protección de datos personales en las redes sociales», Anuario Iberoamericano de Derecho notarial, № I, 20I2, pág. 445.

${ }^{26}$ CALAZA LóPEZ, S., «Delimitación de la protección civil del derecho al honor, a la intimidad y a la propia imagen », Revista de Derecho UNED, № 9, 20II, pág. 55.

${ }^{27}$ Es fundamental la STS de 28 de octubre de I986, sobre el Caso Paquirri, relativa a la intimidad, en la que por, primera vez, se menciona también la imagen. Por su parte, sentencias del Tribunal Supremo como la I39/200I, de I8 de junio, rec. 4824/I997, I56/200I, de 2 de julio, rec. 464I/I998 o la 400/2009, rec. 245I/2005, de I2 de junio señalan que, cuando se publican fotografías de personas desnudas en las playas o sin la parte superior del bikini en actitudes no reveladoras de momentos íntimos de su vida privada para su reputación y buen nombre, las mismas, únicamente pueden afectar al derecho a la propia imagen y no, además, a los derechos fundamentales al honor y a la intimidad. 
producirá cuando las imágenes permitan la identificación de la persona fotografiada o que ésta pueda ser identificable, pero no entrañen una intromisión a la intimidad.

Y, además, a los anteriores casos, se ha de sumar otra posibilidad. Y es que, aunque el ámbito propio del derecho a la propia imagen sea la protección del individuo frente a las reproducciones gráficas de una persona que no lesionen el derecho a la intimidad, no cabe descartar la vulneración de aquél derecho a la propia imagen, en los casos en los que la difusión de la misma revele aspectos de su vida privada, permitiendo identificar a la persona fotografiada. En estos casos, la propia imagen es instrumental del derecho a la intimidad.

Y en un último término, la estrecha relación de los derechos a la intimidad personal y a la propia imagen, ambos pertenecientes al ámbito de la vida privada ${ }^{28}$, uno en la vertiente de protección ad intra, el otro ad extra, puede verse completada, al mismo tiempo, con la vulneración del tercero de los derechos del art. I8 CE: el derecho al honor ${ }^{29}$.

\section{III.3. El derecho al honor}

El derecho al honor, aún partícipe de un concepto jurídico normativo ${ }^{30}$ y con las dificultades conceptuales que ello conlleva ${ }^{31}$, ha sido definido como honra, una especie de «patrimonio moral de la persona» consistente en aquellas condiciones que se consideran expresión concreta de su propia estimación o, en sentido objetivo, como reputación, es decir, la opinión o estima que de la persona tienen los demás. Se apunta desde la propia Ley que la falta de precisión en la definición conceptual de estos derechos permite que se vayan adaptando a los valores, las ideas y las normas sociales de cada momento. Efectivamente, estas lagunas no son un defecto sino una virtud. Por eso, en la actualidad oímos hablar del término reputación online, una traslación del bien jurídico protegido por el derecho al honor al mundo digital o, si se quiere, una redefinición del derecho en este nuevo contexto. El «apellido» online afecta no tanto al concepto de reputación, como al modo de construirla,

\footnotetext{
${ }^{28}$ Cfr. STC I70/1987, de 30 de octubre, rec. 383/1986, FJ 4 (RTC I897, I70).

${ }^{29}$ Rico CARrillo, M., «El derecho al honor, intimidad e imagen y la protección de datos personales en las redes sociales», Anuario Iberoamericano de Derecho notarial, $\mathrm{N}^{\circ} \mathrm{I}, 20 \mathrm{I} 2$, pág. 450. Este el caso de la SAP de Madrid, de I3 de septiembre de 2005 , en la que la revista «Lecturas» publica, a propósito de la crisis matrimonial de la pareja integrada por la duquesa y el torero, la supuesta adicción al sexo de él, que le habría llevado -según la noticia- a recibir terapia para suspender la adicción y obtener el perdón de su esposa. Esta publicación, inveraz, supuso no sólo una intromisión en la vida privada de estas personas, sino también una intromisión en el derecho al honor de él. Asimismo, la Audiencia Provincial de Cádiz, en su Sentencia de 2I de septiembre de 2004 consideró que lesionaba el honor y la intimidad un cartel en el que figuraba «Diploma de moroso concedido a $\mathrm{D}^{a}$. Daniela mérito concedido por esta empresa». Disiente MACíAs CASTILlo de que, en este caso, se afecte a la intimidad, lo que demuestra la difícil separación en algunos casos, de la tenue frontera que separa el honor de la intimidad de las personas. MACías CASTILlo A. «Derecho a la intimidad y libertad de expresión e información», Práctica de Derecho de Daños, Núm. 47,La Ley, 2007 (disponible en: www.laleydigital.laley.es), fecha de consulta II/I2/20I5.

${ }^{30} \mathrm{El}$ «honor» se ha calificado jurisprudencialmente como un concepto jurídico indeterminado, cambiante en función de las normas, valores e ideas sociales vigentes en cada momento. Ver a este respecto la STC I70/I994, de 7 de junio FJ $4^{\circ}$ (RTC I994, II70).

${ }^{31}$ SAnChís Crespo, C., «La tutela judicial del derecho al honor, Internet y la blogosfera», Diario La Ley, No8035, 2013, págs.I-I5.
} 
mantenerla y defenderla, en atención a la repercusión y alcance que toma. Así, cualquier persona posee la capacidad de lanzar información en las redes sociales, que a su vez, es susceptible de ser enlazada o compartida o indexada, alcanzando una difusión incontrolable $e^{32}$.

De esta manera, la imagen difundida puede menoscabar la reputación y buen nombre de aquél que aparece en ella. Muestra de ello es el caso del becario estadounidense que, tras pedir permiso para ausentarse del trabajo por razones familiares urgentes, fue despedido con motivo de la publicación, y consecuente conocimiento de su empleador, de una fotografía en la que aparecía en una fiesta de Halloween. Uno de sus compañeros no sólo publicó, sino que también le etiquetó, situación que motivó el despido ${ }^{33}$.

Pero las funcionalidades de la web 2.0 no se limitan a permitir la publicación de fotografías a los usuarios sino que permiten la posibilidad incluir comentarios. Al mismo tiempo, las amplias posibilidades de manipulación sobre la imagen por medios técnicos, supone un riesgo de la desnaturalización de su dimensión personal. Todas ellas son vías de lesionar el derecho al honor en estos contextos ${ }^{34}$.

III.4. El derecho a la protección de datos

Si dijéramos que, en lo hasta aquí expuesto, hemos recorrido todos los derechos del art. I8 vulnerados por la difusión de imágenes sin consentimiento en las SRS, estaríamos pasando un derecho, es más, un derecho de carácter «fundamental», en el sentido jurídico del término, por alto: el derecho a la protección de datos del art. I8.4 $\mathrm{CE}^{35}$. Como es sabido, este derecho «advenedizo» garantiza, entre otras cosas, la facultad del individuo de decidir básicamente por sí mismo sobre la difusión y la utilización de sus datos personales, sean íntimos o no. Por ello, cuando se trata de una imagen o fotografía además de la vulneración de los derechos comentados, se produce lesión del derecho a la protección de datos ${ }^{36}$, en el

\footnotetext{
${ }^{32}$ InSTITUTO NACIONAL DE CiberSEguRIDAd (INCIBE), Guía para usuarios: identidad digital y reputación online, 20I2, disponible en: https://www.incibe.es/file/QeTWH8vXMiMtSH7Apl5n5Q (fecha de consulta:23/II/2015).

${ }^{33}$ Rico CARrillo, M., «El impacto de Internet y las redes sociales en el derecho a la libertad de expresión», Revista de Filosofía Jurídica, Social y Política, N 3, 20I2, pág. 347, disponible en

www.corteidh.or.cr/tablas/r32923, (fecha de consulta I8/II/20I5)

${ }^{34}$ Se abre el tema así a la problemática suscitada a raíz de los fotomontajes y caricaturas en las que, por motivos de espacio, no tenemos oportunidad de entrar. Al respecto, encontramos abundante jurisprudencia entre la que cabe destacar la STS i85/2006, de 7 de marzo, rec. 2213/2000.

${ }^{35}$ La consagración del derecho fundamental a la protección de datos de carácter autónomo y los consecuentes derechos dimanantes del habeas data se produce gracias a las SSTC 290/2000, de 30 de noviembre, rec. 20I/I993 y 292/2000, de 30 de noviembre, rec. I463/2000. La primera señalaba que «(...) el derecho fundamental a la protección de datos, a diferencia del derecho a la intimidad del art. I8.I C.E., con quien comparte el objetivo de ofrecer una eficaz protección constitucional de la vida privada personal y familiar, atribuye a su titular un haz de facultades que consiste en su mayor parte en el poder jurídico de imponer a terceros la realización u omisión de determinados comportamientos cuya concreta regulación debe establecerla la Ley».

${ }^{36}$ Aunque el concepto original de dato personal incluido en la LOPD indica de manera genérica que se trata de «cualquier información concerniente a personas físicas identificadas o identificables», la definición del artículo 5 del RLOPD se refiere a «cualquier información numérica, alfabética, gráfica, acústica o de cualquier otro tipo concerniente a personas físicas identificadas o identificables».
} 
entendido de que una fotografía que contenga la imagen de una persona y permita su identificación es un dato de carácter personal ${ }^{37}$. Ello determinará, como veremos en el apartado oportuno y siempre que se cumplan los requisitos preceptuados, la aplicación de la normativa de protección de datos.

Sin embargo, llegar a esta inmediata conclusión no ha llevado pocos debates. Sobre el tratamiento de datos, no existen dudas de que este elemento se configura en las SRS dado que se trata de un concepto amplio que incluye una diversidad de actividades entre las que se encuentran «...la recogida, grabación, conservación, elaboración, bloqueo y cancelación...», ya sean realizadas por los prestadores de servicios (en adelante, PSRS) o por los usuarios $^{38}$. Mucho menos sobre la condición de «dato personal» de una imagen o la calidad de interesado. El origen de esta controversia, por tanto, se encuentra en la normativa que desarrolla este derecho fundamental, cuando excepciona de la protección de datos a los ficheros mantenidos por personas físicas en el ejercicio de actividades exclusivamente personales o domésticas ${ }^{39}$. Lo que nos lleva inmediatamente a preguntarnos si las RSI pudieran entrar dentro del ámbito de las actividades personales. La respuesta en este caso es negativa, aunque con matices. En una línea tuitiva, se ha venido considerado que el elevado número de contactos que caracteriza a las redes sociales impide la aplicación de la excepción ${ }^{40}$. Sin embargo, el nuevo Reglamento de Protección de datos cambiará con su entrada en vigor esta consideración, haciendo extensible la excepción a las redes sociales ${ }^{4 \mathrm{I}}$.

En consecuencia, por el momento, cuando se obtiene una imagen de una persona y se difunde sin haber obtenido previamente su consentimiento en SRI -a menos que se trate de una red privada, exclusivamente familiar-, se conculca el derecho a la protección de

\footnotetext{
${ }^{37}$ Sobre este particular, hemos de destacar que en España es notable la sentencia del Juzgado de Instrucción núm. 4 de Sevilla 67/2009, de 25 de febrero, que condena a una persona que había publicado en Tuenti unas fotografías de un menor retocadas a través de software de edición digital, ocasionando comentarios despectivos por parte de otros usuarios de la red hacia la víctima, acción considerada por el Juez como un ataque a la dignidad personal del denunciante, en particular en lo que se refiere al respeto al honor e imagen.

${ }^{38} \mathrm{Ambos}$ pueden ser considerados responsables del tratamiento de esos datos, como veremos en el apartado correspondiente de este trabajo.

${ }^{39}$ Art.4 LOPD «...sólo se consideran relacionados con actividades personales o domésticas los tratamientos relativos a las actividades que se inscriben en el marco de la vida privada o familiar de los particulares».

${ }^{40}$ Así se estableció en la Sentencia del Tribunal de Justicia de 6 de noviembre de 2003, Asunto C IOI/OI, (disponible en http://curia.eu/), que determinó exigibles la normativa de protección de datos a la Sra. Lindqvist (fecha de consulta: I9/II/IOI5).

Ver Dictamen 5/2009, sobre redes sociales en línea, adoptado el I2 de junio de 2009, pág. 6. Apuesta por la misma línea la Propuesta del Reglamento de 25 de enero de 2012 que, aclara, igualmente, que un número muy elevado de contactos por parte de un usuario implica una aceptación indiscriminada de peticiones de amistad sin que exista una relación personal, por lo que no puede hablarse de datos que afecten a la esfera personal. Y añade que tampoco puede considerarse tratamiento personal y doméstico cuando el perfil y los contactos personales se encuentran abiertos para todos los usuarios de la red social o cuando la información pueda ser indexada a través de los motores de búsqueda. Propuesta del Reglamento General aprobado el 25 de enero de 2012 por la Comisión Europea y el Consejo relativo a la Protección de Datos Personales y a la libre circulación de estos datos, disponible en:

http://ec.europa.eu/justice/data-protection/document/review20I2/com_20I2_II_es.pdf (fecha de consulta 20/12/20I5).

${ }^{41}$ Considerando I8 del Reglamento de Protección de Datos, de 27 de abril de 20I6: «Entre las actividades personales o domésticas cabe incluir la correspondencia y la llevanza de un repertorio de direcciones o la actividad en las redes sociales y la actividad en línea realizada en el contexto de las citadas actividades».
} 
datos.

Lo anterior nos lleva a constatar que la vulneración del derecho a la protección de datos en principio irá inescindiblemente unida a la lesión del derecho a la propia imagen ${ }^{42}$. No necesariamente, al derecho a la intimidad, por relacionados que resulten, incluso a ojos de la jurisprudencia ${ }^{43}$, la «privacidad» que protege el derecho a la protección de datos del art. I8.4 CE con el derecho a la intimidad. Al contra, se trata de derechos autónomos, con un ámbito de protección de distinta amplitud, aunque parcialmente coincidente ${ }^{44}$. Coincidencia que no ha pasado inadvertida para el Grupo de Trabajo del artículo 29 y para la Agencia Española de Protección de Datos (en adelante, AEPD). Basta ver sus informes para verificar hasta qué punto se corre el riesgo de reducir la mayor parte del art. i8 de la Constitución española a la protección de datos ${ }^{45}$. Desde esta perspectiva, el derecho a la protección de datos podría verse como un derecho con un poder de atracción excesivo, desde otra mucho más constructiva, como un derecho que redunda en una protección adicional, instrumental ${ }^{46}$.

\section{Análisis de los derechos del artículo 20}

Hemos visto cómo la difusión de imágenes sin la autorización del afectado en las SRS puede provocar la lesión de los derechos reconocidos en el art. I8 de nuestra Constitución. Ahora bien, escaso valor tendía este examen si no analizamos, siquiera someramente, la libertad de expresión e información con la que pueden entrar en conflicto.

Como caras de una misma moneda, los derechos de del art. I8 y del art. 20 son límites entre sí. La clave está no tanto en determinar qué abarca cada derecho sino cuándo se ejerce de manera correcta. Y ello porque no siempre existe un choque real de derechos, que nos situaría en una encrucijada constitucional con la ponderación como única salida, sino que, en gran parte de las ocasiones, se ejercitan de manera incorrecta debiendo decaer ante los derechos al honor, a la intimidad personal y familiar y a la propia imagen.

El punto de partida que hemos de tomar es la posición preferente de las libertades

${ }^{42}$ Con la incorporación en los siglos XX y XXI de la posibilidad de tratar automatizadamente la imagen obtenida desde las diversas tecnologías, la protección del derecho a la imagen irrumpe en la escena jurídica, además de cómo derecho de la personalidad, también como dato (la imagen lo es) de los protegidos en el tratamiento automatizado a que se refiere el art. I8.4 CE. VELASCO NúÑEZ, E., «Derecho a la imagen: tratamiento procesal penal», Diario La Ley, No 8595, 2015, pág. 2.

${ }^{43}$ Valgan de ejemplo las sentencias I64I/2000, de 23 de octubre, rec. 465/1999; 694/2003, de 20 de junio, rec. 2667/200I; 249/2008, de 20 de mayo, rec. I0983/2007.

${ }^{44}$ Rico CARrillo, M., «Las implicaciones de Facebook en el derecho al honor, la intimidad personal y familiar y la propia imagen», Revista de contratación electrónica, N II7, 20I2, pág. 36.

${ }^{45}$ Para un estudio más profundo sobre esta cuestión: MARTínez MARTíneZ, R., «El derecho fundamental a la protección de datos: perspectivas», Revista de los Estudios de Derecho y Ciencia Política de la UOC, No 5, 2007, págs. 47-6r.

${ }^{46} \mathrm{~A}$ la vista de que, en muchos de los casos en los que estén en juego los derechos del art. I8 CE existirán tratamientos de datos personales, el Tribunal Supremo ha aclarado que la clave consiste en situar el derecho fundamental de la protección de datos en el plano de la función instrumental. Vid. STS 254/I993 de 20 de julio, rec. $1827 /$ I990. 
de expresión e información, derivada de una doble naturaleza de la que carecen los derechos recogidos en el art. I8 CE. Además de derechos fundamentales, la libertad expresión y el derecho de información constituyen garantías de una opinión pública libre, indisolublemente unida al pluralismo político, valor fundamental y requisito de funcionamiento del Estado democrático ${ }^{47}$.

Pero ni todo es blanco, ni todo es negro, y esa prevalencia de las libertades de expresión e información sobre los derechos al honor, intimidad y propia imagen no es, ni mucho menos, absoluta. Se trata de una prevalencia «funcional». Esto es, prevalecen siempre que se ejerciten conforme a su naturaleza y función, de acuerdo a los parámetros constitucionales $^{48}$. Como finalmente veremos, esta «relativización» de la prevalencia de estos derechos pasa por: primero, en sede de las libertades de expresión e información, atender a su correcto ejercicio de acuerdo a los requisitos legales, y; segundo, en relación al honor, la intimidad y la propia imagen, estar a la variación del alcance e intensidad de protección en función de la condición del titular y, en tanto estamos hablando de la captación y difusión de imágenes, al lugar donde éstas se hayan tomado ${ }^{49}$.

Aclarado lo anterior, comenzaremos señalando que el primer derecho que reconoce y protege el artículo 20 de nuestra Constitución es el derecho a expresar y difundir libremente los pensamientos, ideas y opiniones mediante la palabra, el escrito o cualquier otro medio de reproducción, sin pretensión alguna de sentar hechos o afirmar datos objetivos $^{50}$. Teniendo en cuenta que los límites a cualquier derecho, también el de expresión, han de ser los mismos, sea donde fuere que se ejerciten, esta libertad fundamental comprende, según opinión reiterada del Tribunal Constitucional, junto a la mera expresión de juicios de valor, la crítica de la conducta de otro, aun cuando la misma sea desabrida y pueda molestar, inquietar o disgustar ${ }^{\text {51 }}$. Y su espacio «estrella», son las SRS.

Además, de la libertad de expresión, el otro derecho al que da cobijo el art. 20 del texto constitucional es la libertad de información, en su doble vertiente. Este derecho reconoce y protege el derecho a comunicar o recibir libremente información veraz por cualquier medio de difusión. Se trata de un derecho con doble perspectiva, que se concreta en comunicar información y recibirla de manera libre ${ }^{52}$. Esta comunicación debe reunir los requisitos de veracidad ${ }^{53}$, interés y relevancia y, por último, el de corrección de formas ${ }^{54}$.

\footnotetext{
${ }^{47} \mathrm{STC}$ I72/I990, de I2 de noviembre, rec. 803/ I988,FJ $2^{\circ}$.

${ }^{48}$ En contraposición con una finalidad difamatoria o vejatoria. Véase STC I7I/I990, de I2 de noviembre, rec. I7I/I990, FJ $5^{\circ}$ (RTC I990, I7I).

${ }^{49}$ Ver Anexo, Tabla I.

${ }^{50}$ Nuestro Tribunal Constitucional viene recordando que la libertad de expresión garantiza la comunicación pública libre sin la cual quedarían vaciados de contenido otros derechos que la constitución consagra (STC 235/2007, de 7 de noviembre, FJ 4 ${ }^{\circ}$, RTC 2007, 235).

${ }^{51}$ V.gr. STC Pleno, I77/2015, de 22 de julio, rec. 956/2009.

${ }^{52} V i d$., FJ II ${ }^{\circ}$ de la STC I05/1983, de 23 de noviembre, rec. I07/1983.

${ }^{53}$ El requisito de veracidad de la información merece distinto tratamiento según se trata del derecho al honor o del derecho a la intimidad, ya que, mientras la veracidad funciona, en principio, como causa legitimadora de las intromisiones al honor, si se trata del derecho a la intimidad, actúa en sentido diverso. A este respecto, ver la STC i97/I99I, de I7 de octubre, rec. 492/1989.
} 
Pero, más allá de verificar su cumplimiento, debemos preguntarnos antes si es un derecho que tiene cabida en las SRS. En otras palabras: ¿Es Internet un medio de comunicación social, de difusión?

Si la respuesta fuera positiva, podría entenderse que, atendidas las circunstancias del caso concreto, el derecho a la información debería ser preferente. Por el contrario, si concluimos que no es un medio de comunicación social, esa preferencia del derecho a la información podría decaer, al entender con ello que no hay una «opinión pública» que proteger.

Bien, pensemos en las imágenes que esta madrugada ha podido publicar El País o El Mundo en su cuenta de Twitter o, si se quiere, cualquier usuario en Facebook o en su canal de YouTube. Y es que también suele ser habitual la utilización de imágenes en las redes sociales con fines de pretendido "periodismo ciudadano», que pueden respetar o no los límites que el ejercicio del derecho a la información. A simple vista parece lógico pensar que, al menos en el primer caso, estamos ante un medio de comunicación social. Pues bien, la Directiva 2010/13/UE se ha encargado de aclararnos que no estamos en lo cierto. En este sentido, señala que no debe aplicarse a las versiones electrónicas de periódicos o revistas ${ }^{55}$. A este respecto, viene a matizar la sentencia del Tribunal de Justicia conocida como New Media Online que, pese a la presencia de elementos audiovisuales, no debe ser considerada un servicio de comunicación audiovisual «cuando tales elementos sean incidentales y sirvan únicamente para completar la oferta de los artículos de prensa escrita» ${ }^{56}$.

Pero, para consuelo de los que estudiamos la materia, el hecho que no nos encontremos ante «servicios de comunicación audiovisual», en sentido estricto, y, por lo tanto, no sea aplicable el régimen jurídico de la Ley General de Comunicación Audiovisual (en adelante, $\mathrm{LGCA}^{57}$ ), no implica que se haya de desatender el hecho de que la comunicación la realicen profesionales. Si como dice la jurisprudencia constitucional, el derecho a la información alcanza su máximo nivel cuando la libertad es ejercitada por los profesionales de la información, entiendo, que esta aseveración debe hacerse extensible, aun cuando la comunicación se produzca a través de $\mathrm{SRS}^{58}$. Haciéndose, del mismo modo, aplicable una mayor diligencia exigible, dada la especialidad del medio ${ }^{59}$.

Ahora bien, y ¿qué ocurre, si como apuntábamos antes, la publicación procede de un usuario corriente? Sabemos que, el impacto de las Web 2.0 ha supuesto la mutación del

\footnotetext{
${ }^{54}$ Sentencia del Tribunal Supremo 706/2004, de 2 de julio, rec. 2073/1999.

${ }^{55}$ Cdo. 28 de la Directiva.

${ }^{56}$ Sentencia del Tribunal Superior de Justicia de 2I de octubre, C- 347/I4.

${ }^{57}$ Ley 7/20Io, de 3I de marzo, General de Comunicación Audiovisual.

${ }^{58} \mathrm{La}$ STC 74/2010, de 3 de marzo, rec. 2766/200I, en su FJ $4^{\circ}$ establece que «La protección constitucional de las libertades de información y expresión alcanza un máximo nivel cuando la libertad es ejercitada por los profesionales de la información a través del vehículo institucionalizado de formación de la opinión que es la prensa, entendida en su más amplia acepción».
}

${ }^{59}$ Así opina Mesía de la Cerda Ballesteros, J. A., «Implicaciones del uso de internet en la protección del derecho al honor», Actualidad civil, $\mathrm{N}^{\circ}$ 4, 20I4, pág. 422, disponible en laleydigital.laley.es (fecha de consulta I6/II/20I5). 
receptor pasivo de la comunicación a un creador y gestor de contenidos ${ }^{60}$. Sin embargo, al igual que en el caso anterior, parece que tampoco estamos ante un «servicio de comunicación audiovisual», una calificación que se reserva a los medios de comunicación de masas, en el sentido de estar destinados a una parte significativa del público en general. La Ley aclara que quedan excluidos los «sitios web de titularidad privada» ${ }^{6 \mathrm{I}}$, en la medida en quedan excluidas actividades que no son fundamentalmente económicas ni entran en competencia con la radiodifusión televisiva, sino que comparten e intercambian contenido en grupos de interés. Por mucho que esta exclusión se fundamentara en preservar la «libertad de Internet» ${ }^{62}$, no deja de presentar dudas la delimitación de cuándo un servicio tiene naturaleza económica, especialmente a la vista del negocio que suponen en determinados supuestos ${ }^{63}$.

Sin embargo, como hemos precisado anteriormente, el que no se aplique el régimen de la LGCA, no impide que se pueda ejercer este derecho, aun cuando, en este caso, no alcance el mismo nivel de protección que si se tratara de profesionales. Como sabemos, el derecho de información no es exclusivo de los medios de comunicación ni de sus profesionales sino que corresponde a todos los ciudadanos, no existiendo hoy en día medio de comunicación social más común que una página web, pues en todas ellas, al margen de su titularidad lo que se pretende es comunicar un mensaje, que todo el mundo tenga conocimiento de lo que en ellas se publica, con independencia de que se trata de la página web de un medio institucionalizado o no $^{64}$.

No obstante, lo racional de esta conclusión no ha impedido que, desde ciertos ámbitos, incluso jurisprudenciales ${ }^{65}$, se haya entendido que el usuario no es más que un sujeto que se expresa en un grupo formado previa autorización de un tercero, el prestador de servicios, que es quien tiene, en último término, el control sobre los contenidos, así como sobre la publicidad que muestran ${ }^{66}$. A la misma idea nos lleva el Informe A/65/284 de la $\mathrm{ONU}^{67}$ cuando se refiere al periodismo ciudadano como ejercicio de la libertad de expresión

\footnotetext{
${ }^{60} \mathrm{Se}$ ha producido la ruptura del paradigma tradicional de la comunicación consistente en la traída del emisor-canal-receptor, donde el mensaje ya no es unidireccional, sino que fluye de manera transversal hasta convertirse en una gran conversación global y multidireccional gracias a la accesibilidad, instantaneidad y viralidad de la red. Los social media o medios sociales nacen como contraposición a los mass media, pasando de un público homogéneo y pasivo a otro heterogéneo y activo.

${ }^{6}$ Traducción de la expresión inglesa private websites de la Directiva 2010/13/UE.

${ }^{62} \mathrm{La}$ queja de los internautas ante el temor de que la libertad de Internet desapareciera motivó que el Grupo Ezquerra Republicana- Izquierda Unida- Iniciativa per Catalunya Verds solicitara el cambio de la redacción del Proyecto de Ley para hacer constar de manera clara esta exclusión a través de la enmienda n I99. BOE núm. 456 , de 17 de diciembre de 2009 .

${ }^{63}$ Téngase en cuenta las elevadas cantidades de dinero que ganan algunos youtubers. A este respecto, puede verse The Worlds Highest-Paid Youtube Stars 2015, disponible en: www.forbes.com (fecha de consulta: I7/II/20I5).

${ }^{64}$ Contreras Navidad, S., La Protección del Honor, la Intimidad ... op.cit. , pág. 43.

${ }^{65}$ En este sentido, la SAP de Tarragona 420/2005, de io de octubre, rec. 69/2005 respecto a los dominios www.idiada.net, www.idiada.org y www.idiada.info.

${ }^{66}$ LÓPEZ GARCíA, M., «Internet: ¿'medio de comunicación audiovisual?», Revista TELOS (Cuadernos de Comunicación e Innovación), 20II, págs. 3-4, disponible en: www.telos.es (fecha de consulta 20/II/20I5).

${ }^{67}$ El Relator define el término periodismo ciudadano como un «periodismo independiente, a menudo realizado por aficionados en el escenario de un acontecimiento y difundido a nivel mundial por medios
} 
de periodistas no profesionales, de ciudadanos comunes que realizan actividades periodísticas con un mayor o menor cumplimiento de las normas éticas de la profesión ${ }^{68}$. De ahí que haya quienes sostienen que este periodismo ciudadano tiene «más de ciudadano que de periodismo» ${ }^{69}$.

Es aquí donde vemos que, al igual que los derechos del art. I8 CE, los derechos de libertad de información y expresión también están relacionados, más cuando nos referimos a una SRS donde todo está marcado por la impronta de la identidad digital del usuario ${ }^{70}$, haciendo que, no siempre con fortuna, se confunda libertad de información con libertad de expresión.

Llegados a este punto, hemos de resaltar que esta «prevalencia», no tiene el mismo peso frente a cada uno de los derechos recogidos en el art. I8 CE. En el caso del derecho a la protección de datos, determinadas decisiones legislativas han llevado a consolidar la primacía del derecho de información ${ }^{71}$. Por otro lado, la prevalencia del derecho a la información sobre el derecho a la imagen es mayor que sobre el derecho a la intimidad. En este sentido, se ha de añadir también que la jurisprudencia reciente ha optado por la prevalencia de la libertad de información (e incluso, de expresión) frente al honor, dado que el cumplimiento de los requisitos de su ejercicio, hace que la afección al honor sea de baja intensidad, incluso ante la concurrencia de expresiones insultantes, al entender que las mismas se justifican en un contexto de alarma social sobre los temas que motivan las opiniones e informaciones ${ }^{72}$.

Más complejo resulta determinar estas relaciones en el caso de la libertad de expresión. El hecho de que lo único que limite este derecho frente al derecho al honor, la intimidad y la propia imagen radique en las afirmaciones injuriosas e innecesarias para la formación adecuada de la opinión pública, hace que resulte, a priori, fuera de un análisis casuístico, casi imposible determinar la prevalencia de este derecho que, en todo caso,

modernos, fundamentalmente por internet (mediante sitios de intercambio de fotos, vídeos, microblogs, foros en línea, tableros de anuncios electrónicos, redes sociales, podcasts y otros). Informe A/65/284 de la Asamblea General de Naciones Unidas, de iı de agosto de 20I0, sobre la Promoción y protección del derecho a la libertad de opinión y de expresión.

${ }^{68}$ Parte de la doctrina se niega a aceptar esta simplicidad apuntando a un examen casuístico, en el que, cuando un ciudadano informe siguiendo los principios éticos de la profesión, con independencia de que pertenezca a un medio de comunicación o no, es un periodista, aplicándosele su régimen legal. ESPIRITUSANTO, O., GonZalo Rodríguez, P., Periodismo ciudadano: Evolución positiva de la comunicación, Barcelona, Ariel, 20II, págs. I44-I45.

${ }^{69}$ Alex Grijelmo, Presidente de la Agencia de Noticias Efe. Entrevista publicada en el diario digital www.eltiempo.com (fecha de consulta: I8/II/20I5).

${ }^{70} \mathrm{No}$ siempre es fácil separar la expresión de pensamientos, ideas y opiniones de la estricta comunicación informativa, pues la expresión de pensamientos necesita a menudo apoyarse en la narración de hechos y, a la inversa, la comunicación de hechos o de noticias no se da nunca en un estado químicamente puro y comprende, casi siempre, algún elemento valorativo o, dicho de otro modo, un avocación a la formación de una opinión. STC 6I/I988, de 2i de enero, FJ $5^{\circ}$ (RTC I988).

${ }^{71}$ En la transposición de la Directiva 95/46/CE no se ha utilizado la habilitación que concede su artículo 9 para fijar condiciones al ejercicio de la libertad de expresión respetuosas con la intimidad.

${ }^{72}$ Cfr. Mesía de la Cerda Ballesteros, J. A., «Implicaciones del uso de internet ...», cit., pág. 425, disponible en laleydigital.laley.es (fecha de consulta I8/II/20I5). 
requiere extremar la cautela ${ }^{73}$.

\section{El consentimiento como elemento esencial}

En lo hasta aquí expuesto, nos hemos referido a la difusión de imágenes «sin consentimiento», «sin autorización», «inconsentidas», etc. Es evidente que podemos estar de acuerdo en que hablamos de captación y difusión de imágenes en contra de la voluntad del titular del derecho. Pero, ¿cuándo hay exactamente consentimiento? El tema no es baladí. Entender que media consentimiento, marca la diferencia entre estar ante una intromisión ilegítima de estos derechos o no estarlo.

Para responder a esta pregunta, debemos partir de que los derechos al honor, la intimidad y la propia imagen son res extra comercium. Si, son irrenunciables. Y, no, no nos encontramos ante un absurdo. Efectivamente, el art. I.3 LO I/I982 dispone que, además de inalienables e imprescriptibles, los derechos al honor, intimidad y propia imagen son irrenunciables, incluyendo, el mismo texto legal, tan sólo un artículo más abajo, el consentimiento como causa justificada de intromisión ${ }^{74}$. Es, precisamente, esta aparente contradicción, la que marca las claves del régimen del consentimiento ${ }^{75}$.

De esta forma, el hecho de que estos derechos resulten irrenunciables determina que el consentimiento sólo tenga cabida cuando no permita la renuncia completa y para siempre del derecho, sino una disposición parcial, eventual y concreta, incluso, delimitada en el tiempo ${ }^{76}$. Estas notas justifican la cautela de que el mismo sea expreso, como establece la ley y, como complementa la doctrina y la jurisprudencia, deba estar suficientemente informado ${ }^{77}$, no teniendo cabida, en ningún caso, el consentimiento presunto ${ }^{78}$.

Da la impresión de que tenemos frente a nosotros, un régimen del consentimiento formal y estricto, en el que éste, como causa tipificada de intromisión, estaría limitado, garantizado y reforzado. Pero pronto nos damos cuenta de que la realidad es muy distinta. Y es que, razones pragmáticas y de sentido común - nótese que éste no es lugar exento a la

\footnotetext{
${ }^{73}$ Estas consideraciones no pueden extrapolarse a ámbitos como el militar, donde, como ha venido la jurisprudencia a decir recientemente, los límites son más estrictos que en lo civil. Información disponible en: http://www.expansion.com/juridico/sentencias/20I6/12/o9/584aeba5268ezed92e8b466b.html (fecha de consulta: $16 / \mathrm{i2} / 20 \mathrm{I} 6)$.

${ }^{74} \mathrm{El}$ art. 2.2 de la LO I/I982 dispone que « (...) no se apreciará la existencia de intromisión ilegítima en el ámbito protegido (...) cuando el titular del derecho hubiese otorgado al efecto su consentimiento escrito».

${ }^{75}$ Es irrelevante acudir a las teorías doctrinales que explican con rebuscadas explicaciones la convivencia de ambos preceptos, pues como aprecia MéNDEZ Tojo, con una explicación u otra el resultado es el mismo. MÉndez Tojo, R., «Los conflictos entre el derecho al honor, la intimidad personal y la propia imagen y las libertades de expresión e información ¿'son derechos fundamentales irreconciliables? », Diario La Ley, No 8573, 20I5, pág. 9 (disponible en: www.laleydigital.laley.es).

${ }^{76}$ De ahí que pueda ejercitarse la revocación del consentimiento, según el art. 2.3 LO I/I98I. Cfr. STS II7/I994, de 25 de abril, rec. 20I6/I990 que inhabilita la revocación a efectos de difusión para el pasado.

${ }^{77}$ Velasco NúÑEZ, E., «Derecho a la imagen: tratamiento procesal penal», Diario La Ley, No 8595, 20I5, pág. 3.

${ }^{78}$ Así lo ha declarado la STS I3I/2006, de 22 de febrero, rec. 2926/200I, cuando determina que la falta de prueba sobre la existencia o no de consentimiento lleva a la conclusión de que no concurrió.
} 
aplicación de la doctrina de los actos propios-, nos han obligado a «despegarnos» del papel y entender que donde el legislador dice «consentimiento expreso» sólo quería exigir «consentimiento inequívoco» ${ }^{79}$, abriendo con ello la puerta al consentimiento tácito. Y así, a pesar de los ulteriores problemas de prueba que puedan generarse en una eventual reclamación judicial, se entiende que hay consentimiento en la captura de una imagen cuando uno posa ante la cámara para ser fotografiado, cuando es consciente de que le van a tomar una fotografía y no se opone a ella o cuando una vez tomada, no exige su borrado.

Pero no traslademos esta nueva flexibilidad en la forma de prestación del consentimiento - expresa, presunta o tácita- a su alcance o ámbito de disposición. Como decíamos, el consentimiento tiene que ir unido a cada uno de los posibles usos de la imagen -captación, reproducción, manipulación y difusión-, los cuales deberán ser específicamente autorizados ${ }^{8 \circ}$. Retomando el ejemplo anterior, una cosa es posar para que nos tomen una fotografía y otra muy distinta que estemos dando nuestro consentimiento para publicarla ${ }^{8 \mathrm{r}}$. Es este segundo consentimiento con el que no se cuenta en la mayoría de los casos. Por eso, son intromisiones ilegítimas, desde la publicación en un libro de medicina de la imagen de un paciente sin su consentimiento ${ }^{82}$, hasta la práctica habitual hoy en día de la mayoría de locales nocturnos de publicar fotografías de los asistentes en sus perfiles sociales, como reclamo publicitario ${ }^{8_{3}}$. En cualquier caso, el hecho de posar sólo puede interpretarse como aquiescencia o autorización a la obtención de la imagen de quien se expone a la cámara y no a su posterior difusión. De igual forma, si una actriz da su consentimiento para la realización de unas fotos para una revista, no está autorizando alteración de la misma con Photoshop ${ }^{8_{4}}$. Pero lo que es más, que el consentimiento haya de referirse a la imagen real y existente en el momento en el que tiene lugar la captación, sin que aquél ampare per se posteriores manipulaciones o cercenamientos, abarca no sólo una

${ }^{79}$ Salvador Coderch, P, Rubí Puig, A., Ramírez Silva, P., «Imágenes Veladas. Libertad de Información, derecho a la propia imagen y autocensura de los medios», InDret, $\mathrm{N}^{\circ} \mathrm{I}, 20 \mathrm{II}$, pág. I8 (disponible en: http://www.indret.com/es/?ed=46, fecha de consulta 4/12/20I4). A este respecto, es reveladora en la jurisprudencia la STS 3/20IO, de ig de enero de 20I0, en la que O'CALLAGHAN MUÑOZ, X., alude a la sentada teoría de los «actos de inequívoca significación».

${ }^{80}$ VERDA y BEAmONTE, J.R., «El consentimiento como causa de exclusión de la ilegitimidad de la intromisión», en Verda y BeAmonte, J.R., Veinticinco años de Aplicación de la LO 1/1982, de 5 de mayo, de Protección Civil del Derecho al Honor, a la Intimidad Personal y Familiar, a la Intimidad Personal y Familiar y a la Propia imagen, Aranzadi, Pamplona, 2007, pág. 24I.

${ }^{81}$ En este sentido las Sentencias del Tribunal Supremo 608/2004, de I7 de junio, rec. I754/2000 y 695/2004, de 9 de julio, rec. I46/1999, reiteran que la publicación y la consiguiente difusión son enjuiciables con independencia de su captación y reproducción.

${ }^{82}$ Este caso fue resuelto por la SAP Barcelona 2I/2004, de I3 de enero, rec. 486/2003, cuando concluyó que «Ningún acto relevante hallamos en la causa que permita afirmar que el consentimiento para ser fotografiada supusiera la autorización genérica para cualquier uso que, por otro lado, es negado por la actora y no acreditado por el condenado».

${ }^{83}$ En estos casos, y aunque se escapa al objeto de este trabajo, se ha de señalar que la difusión responde asimismo a fines comerciales por lo que estamos en presencia de la vertiente patrimonial del derecho a la imagen.

${ }^{84}$ Recién escribo estas líneas, ha salido a la palestra el caso de Inma Cuesta, una actriz, que denunció públicamente el retoque de unas fotos concedidas para una entrevista que había realizado la revista. La noticia está disponible en elpais.com/elpais/20I5/IO/IO/estilo/I444504289_I45793.htlm (fecha de consulta: I7/IO/20I5). 
manipulación de las características de la fotografía sino también de la idea que transmite. Por ello, hay vulneración al difundir la imagen de un exalcohólico en una noticia al respecto, sin especificar que ya está rehabilitado ${ }^{85}$.

Y dado que se trata de difusión de imágenes - y, por tanto, datos personales- en redes sociales -donde se automatizan-, las anteriores prescripciones deben ser completadas con las que ofrece la LOPD. No encontramos sorpresas en el régimen del consentimiento desarrollado para la protección de datos respecto del previsto en la LO I/I982 sino una mayor concreción y corrección legislativa que, como no podría ser de otra manera, por la superposición de ámbitos que abarcan, viene a corroborar lo previsto por aquella y su jurisprudencia ${ }^{86}$. Sin embargo, recordemos que analizamos la difusión de imágenes de terceros en las redes sociales, y esto me plantea, al menos, la necesidad de realizar dos matizaciones.

La primera matización tiene que ver con la propia configuración de la Web 2.0 y, en concreto, de las redes sociales ${ }^{87}$, en las que el usuario interactúa con otros usuarios que hace que ciertas obligaciones, que normalmente corresponderían en exclusiva a los prestadores de servicios, se trasladen al propio usuario ${ }^{88}$. Desde esta perspectiva, desde el momento en el que publicamos una fotografía en una red social en la que aparecen más personas, nos convertimos en «responsables del tratamiento» ${ }^{89}$. Esto supone algo así como que, para «subir» una fotografía de nuestra celebración de cumpleaños o cena de empresa,

${ }^{85}$ STS de 30 de noviembre de I992, rec. I99I/I990, en la que se consideró lesionado el derecho al honor en vez del derecho a la imagen.

${ }^{86}$ El art. 3.h) de la LO I5/1999 define el consentimiento del interesado como «toda manifestación de voluntad, libre, inequívoca, específica e informada, mediante la que el interesado consienta el tratamiento de datos personales que le conciernen», así como «específico» conforme impone el art. 4.2. La AEPD coincide con el régimen del consentimiento previsto por la Ley I/I982 y así, entre otras cuestiones, entiende que de las citadas características no se infiere necesariamente su carácter expreso, admitiendo el consentimiento tácito (2000-0000).

${ }^{87} \mathrm{Se}$ ha de tener en cuenta que todas las consideraciones aquí hechas se refieren al marco jurídico actual. Con la entrada en vigor del Reglamento de Protección de datos en 2018 (fecha prevista en el art. 99 del Reglamento), la regulación se modifica en tanto la actividades de las redes sociales se considera incluida en la excepción de actividades domésticas.

${ }^{88}$ Así lo consideró el Tribunal de Justicia en la Sentencia de 6 de noviembre de 2003, Asunto C IOI/OI, (disponible en http://curia.eu/), donde determinó exigibles la normativa de protección de datos a la Sra. Lindqvist, una catequista sueca que, a finales de I998, creó varias páginas web para la preparación de la confirmación y que contenían datos personales sobre sus compañeros de parroquia.

Como la doctrina, esta jurisprudencia es plenamente aplicable a las conductas consistentes en publicar una foto, un vídeo o un texto escrito en una red social. MARTínEz MARTínEZ, R., «Protección de Datos Personales y Redes sociaes: un cambio de paradigma» en Rallo Lombarte, A., Martínez Martínez, R. (Coords.), Derecho y Redes Sociales, Navarra, Civitas, 20ı0, págs. 98 y 99.

${ }^{89}$ De acuerdo a la Directiva 95/46, el concepto de tratamiento comprende cualquier operación o conjunto de operaciones efectuadas o no mediante procedimientos automatizados, y aplicadas a datos personales. Concretamente, su art. 2, letra b) enumera varios ejemplos entre los que se incluye la difusión o cualquier otra forma que facilite el acceso a los datos. Como señala la SAN de 20 de octubre de $201 \mathrm{I}$, rec. $347 / 2009$ 《 (...) quien incluye el vídeo en YouTube es el responsable del tratamiento pues decide, a través de dicha inclusión en Internet, sobre la publicación y difusión del citado vídeo, y en definitiva sobre la finalidad del tratamiento, ostentando la condición de responsable del tratamiento. (...) debe considerarse al recurrente responsable del tratamiento y, por tanto, responsable de la infracción por el tratamiento inconsentido de datos consecuencia de la inclusión del vídeo en YouTube». 
tendríamos que informar a cada uno de los presentes en la imagen en los exhaustivos términos que prevé la $\mathrm{LOPD}^{90}$, concediéndoles un plazo de treinta días para manifestar su negativa y advirtiéndoles de que, en caso de no pronunciarse a tal efecto, se en entenderá que consienten el tratamiento de sus datos de carácter personal. A lo que ha de unirse la conveniencia de dejar constancia del consentimiento para poder probarlo en un eventual proceso judicial, porque, no se nos olvide, somos responsables en el ámbito jurisdiccional de las vulneraciones de los derechos de las personas que derivan de la publicación de una imagen en la red ${ }^{91}$.

No hace falta ser muy perspicaz para ver que una aplicación estricta de esta normativa sería impracticable, pues paralizaría las SRS o bien las convertiría en una fuente inagotable de vulneraciones de datos personales de millones de personas. Y pese a que lo anterior no obsta para que se aplique en determinados supuestos especialmente graves la normativa de protección de datos ${ }^{92}$, adaptándonos a la realidad de Internet, se ha apostado, en el resto -y mayoría- de los casos, por priorizar el ejercicio de los derechos de cancelación como método para la resolución de conflictos ${ }^{93}$.

La segunda apreciación tiene que ver con el medio en el que se efectúa la difusión o, más concretamente, con el acceso al mismo. Y es que, aunque la publicación de imágenes se inserta en la actividad posterior de la SRS, es necesario que retrocedamos hasta el momento de registro, cuando con un solo «click», podemos dejar vacías de contenido las previsiones que establecen las leyes de desarrollo de los derechos del art. I8 CE y que, hasta ahora, venimos analizando. Como contratos de adhesión que son, establecen cláusulas predispuestas al usuario quien, además las acepta sin leerlas en la mayoría de los casos (opción no desdeñable si tenemos en cuenta que no las puede modificar) ${ }^{94}$. En este punto, nos podrían preocupar aquellas cláusulas que permitan la publicación de contenidos por otros usuarios sin nuestra autorización o la cesión de datos a terceros, con las que,

\footnotetext{
${ }^{90}$ Arts. 5 y I2.2 de la LOPD y del RLOPD, respectivamente.

${ }^{9}$ Art. I2.3 LOPD.

${ }^{92}$ En determinados supuestos, cabe utilizar el procedimiento sancionador, al objeto de recriminar conductas especialmente graves no amparables en las reglas de Internet. Cabe referirse a la resolución del procedimiento № PS/00479/2008, relativa a la emisión de imágenes en portales que sirven archivos de vídeo, en concreto, YouTube. En este ámbito, la AEPD se ha servido de la doctrina del artículo 29 del Dictamen 4/2004, de II de febrero del Grupo de Trabajo relativo al tratamiento de datos personales mediante la vigilancia por videocámara, y ha concluido que «la captación y reproducción de imágenes de los transeúntes en la calle, que constituyen datos de carácter personal, y su publicación en YouTube, accesible para cualquier usuario de Internet, se encuentra sometida al consentimiento de sus titulares, de conformidad con los dispuesto en el artículo 6.I de la LOPD». En el mismo sentido, la resolución PS/00II7/2008.

${ }^{93}$ Valga de ejemplo el procedimiento TD/00266/2007, en el que la AEPD reconoce el derecho a cancelar los datos publicados que habían sido facilitados por terceros frente al responsable del sitio web. Puede verse esta tendencia en el art. 45.6 de la LOPD, introducido por la reforma operada por la Ley 2/20II, de 4 de marzo, de Economía Sostenible que prevé, en lugar de acordar la apertura del procedimiento sancionador, apercibir al sujeto responsable a fin de que acredite la adopción de medidas correctoras, eso sí, siempre que los hechos fueren constitutivos de infracción leve o grave y el infractor no hubiera sido sancionado con anterioridad.

${ }^{94}$ Sólo los dos principales documentos legales de Facebook, la Declaración de Derechos y Responsabilidades y la Política de Uso de Datos, suman casi más de I5.000 palabras. Y aunque, cada año, la red social clarifica la información y traduce, en la medida de lo posible, los términos legales a lenguaje común, siguen resultando incomprensibles al colectivo general.
} 
paradójicamente, podríamos estar dando nuestro consentimiento para prescindir de é $1^{95}$.

Sin embargo, desde el momento en el que los PSRS permiten que el usuario configure su propia privacidad a través de las medidas de gestión de la red social, no se les puede achacar otra cosa que la configuración inicial predeterminada sea la más pública posible por defecto y no al revés. Por tanto, debe ser el usuario el que establezca el nivel de acceso a su perfil personal, a sus amigos, a los amigos de sus amigos, en toda la red social o fuera de ella. Reside en el propio usuario, por tanto, la posibilidad de limitar y regular el grado de exposición de las informaciones y datos personales que incorporan el resto de usuarios respecto a él ${ }^{96}$. Aun así, la mayor parte de las plataformas permiten que a los motores de búsqueda de los principales buscadores de Internet indexar los perfiles de los usuarios de forma pública en la Red. En algunos casos dicha indexación incluye el nombre del usuario registrado, su fotografía del perfil y el nombre y fotografías del perfil de los amigos o contactos con los que cuenta en la red social ${ }^{97}$.

Se adelanta, así, la barrera de protección a un momento previo a la lesión. Este planteamiento responde a una filosofía preventiva acorde con la dificultad de reparación del daño en estos casos y que tendrá sus consecuencias a la hora de deslindar responsabilidades.

\section{Excepciones a la regla general del consentimiento}

Como toda regla general en Derecho, también la anterior, tiene sus excepciones. Así pues, en determinados casos, podemos prescindir de ese consentimiento, mientras, en

\footnotetext{
${ }^{95}$ El consentimiento al contrato de adhesión a la red social correspondiente, se ejerce habitualmente aceptando la política de privacidad denominada en otras ocasiones «política de protección», «aviso legal» o, en el caso de Facebook, «Declaración de derechos y responsabilidades». Lo relevante es que, como expone la AEPD 93/2008, sobre «Formas de obtener el consentimiento mediante Web: Consentimientos tácitos», aunque en la mayoría de los casos el usuario ni las lea, se considera prueba del consentimiento específico e inequívoco la acreditación de que el programa impide introducir datos sin antes haber aceptado la política de privacidad. En el mismo sentido se pronuncia en el Informe 0300/2009 o en el 0023/2010.

${ }^{96}$ En este sentido, la «Declaración de derechos y responsabilidades de Facebook» establece que «Eres el propietario de todo el contenido y la información que publicas y puedes controlar como se comparte a través de la configuración de la privacidad y de las aplicaciones. (...) 4. Cuando publicas contenido o información con la configuración «Público», significa que permites que todos, incluidas las personas que son ajenas a Facebook, accedan y usen dicha información y la asocien a ti (por ejemplo, tu nombre y foto de perfil)». Asimismo, añade, en su apartado relativo a la seguridad «2. No publicarás contenido que resulte hiriente, intimidatorio, pornográfico, que incite a la violencia o que contenga desnudos o violencia gráfica o injustificada. (...) 4. No utilizarás Facebook para actos ilícitos, engañosos, malintencionados o discriminatorios». Y, específicamente, en relación a la protección de derechos de otras personas, recalca que: «I. No publicarás contenido ni realizarás ninguna acción en Facebook que infrinja o viole los derechos de otros o que viole la ley de algún modo. (...) 9. No etiquetarás a los usuarios ni enviarás invitaciones de correo electrónico a quienes no sean usuarios sin su consentimiento». Disponible en: https://www.facebook.com/terms.php?locale=es_ES (fecha de consulta: 20/12/20I5).

${ }^{97}$ Aunque este aspecto se tratará con mayor detenimiento en el apartado correspondiente, sí se ha de mencionar que la AEPD ha tutelado el derecho a oponerse a la indexación del nombre o de otro tipo de datos (procedimiento TD/00462/2007). Sigue así lo dispuesto en la Resolución sobre «Protección de la privacidad en los servicios de redes sociales» (30 Conferencia Internacional de Autoridades de Protección de Datos y privacidad de I5-I7 de octubre de 2008) en relación al deber de los proveedores de ofrecer configuraciones por defecto que sean respetuosas con la información contenida en los perfiles de usuario, garantizando la no indexabilidad de los perfiles por parte de los motores de búsqueda.
} 
otros, éste se refuerza o se relaja, incluso, hasta ser inexigible. Es decir, la exigencia y el alcance del consentimiento, es la vara de medir de la protección que se otorga a los derechos del art. I8: la ley lo excepciona cuando entiende que otros derechos son más legítimos, o lo refuerza, cuando el sujeto a proteger es más débil. Por eso, como piedra angular que es de la protección de estos derechos, debemos revisar las modulaciones del consentimiento en razón de dos variables: una objetiva, relativa al interés que presenta la imagen; y otra subjetiva, referente a la condición del sujeto que es titular del derecho.

\section{VI.I. Excepciones por razones objetivas}

La publicación en una red social la imagen del último festival de música al que hemos acudido, del disparo del cohete de las fiestas de tu ciudad o de las inundaciones de la «gota fría» son sólo algunos ejemplos en los que no es necesario requerir el consentimiento de aquellas personas que, aunque anónimas, aparecen en la fotografía. No sólo está socialmente, sino también jurídicamente aceptado que la toma de imágenes de terceras personas con motivo de un suceso o acontecimiento público en el que predomine el interés histórico, científico o cultural no se considera una intromisión ilegítima. Así se expresa el art. 8.I de la Ley I/ı982, en una clara coordinación con la con la ponderación constitucional de los derechos del art. I8 y 20 de de nuestra Carta Magna, a la vez que determina el alcance del límite establecido en el art. 20.4, sacrifica el honor, la intimidad y la propia imagen. Por ello, más que estar ante una excepción a la regla general del consentimiento, podría decirse que estamos ante un supuesto en el que los derechos al honor, intimidad y propia imagen ceden ante la libertad de expresión y el derecho a la información. Por lo que ésta no es sino una manifestación concreta de la ponderación constitucional de los derechos del art. I8 y 20 CE.

\section{VI.2. Excepciones por razones subjetivas}

VI.2.I. Personas anónimas y captación «meramente accesoria».

Llama la atención la amplitud que la protección del art. 7.5 LO I/1982 $2^{98}$ otorga a las personas anónimas, que opera frente a la captación, reproducción y publicación, en lugares privados e, incluso, como ha reconocido la jurisprudencia, abiertos al público ${ }^{99}$. Sólo el consentimiento del que habla el art. 2.2 y las excepciones previstas en la misma Ley -ya mencionadas relativas al interés histórico, científico o cultural- eliminan la condición de intromisión ilegítima. Y es, precisamente, cuando concurren esas salvedades, cuando no se requiere el consentimiento de los presentes en la imagen. Me refiero a la captación «meramente accesoria», a la que se alude el art. 8.2.c). Precepto que, en definitiva, no es

\footnotetext{
${ }^{98} \mathrm{El}$ art. 7.5 establece que tendrán la consideración de intromisiones ilegítimas la captación, reproducción o publicación por fotografía, filme o cualquier otro procedimiento, de la imagen de una persona en lugares o momentos de su vida privada o fuera de ellos, a salvo de lo previsto cuando se trata de personajes públicos.

${ }^{99}$ La STS 4I7/2007, de 28 de mayo, rec. 86/2006, reconoce que: «La protección del derecho a la imagen ex art. 7.5 de la LO I/I982 se extiende a los supuestos en que se capte la fotografía en una playa o en otro lugar público sin consentimiento de la persona fotografiada (SSTC 83/2002 y 300/2006, 23 oct.; y TS 6 mayo y I4 nov. 2002, 25 oct. y II nov. 2004, 6 mayo 2005)».
} 
sino una concordancia con el campo en el que los derechos del art. 20 CE prevalecen. Se trata de otra forma de decir que, cuando hay interés histórico, científico o cultural predomina la libertad de expresión e información limitada por que la aparición de personas anónimas sea «accesoria». Pues bien, que la imagen sea «accesoria» no sólo tiene que ver con que sea complementaria con información sino también, en un sentido más material, con el tamaño de la imagen, el plano desde el que se $\operatorname{capta}^{\text {10o }}$ y lo fugaz o repetitiva que sea en caso de que sea vídeo y no imagen lo que se difunde- ${ }^{\text {-or }}$. Precisamente por ello, no se existe intromisión ilegítima en la difusión de una fotografía en la que aparece un policía en el desalojo de unas viviendas ${ }^{\text {102 }}$ o en la reproducción de un vídeo sobre los riesgos en la circulación en el que aparece el cuerpo inerte de una persona fallecida en un accidente de tráfico ${ }^{\text {I03. }}$.

Pese a todo ello, las SRS son a las personas anónimas lo que los medios de comunicación a las populares $\mathrm{y}$, por tanto, las intromisiones son tremendamente habituales.

\section{VI.2.2. Personajes públicos.}

Comentábamos que la Ley limitaba la protección de los derechos al honor, la intimidad y la propia imagen al ámbito que, por sus propios actos, mantenga cada persona reservado para sí misma o su familia ${ }^{\mathrm{I04}}$. A la vista de esta regulación, parece lógico entonces que, a ojos de la ley, no sea lo mismo la difusión de una fotografía de un particular que la de una persona conocida públicamente, hechos también frecuentes en las RSI. Así, el principio conforme al cual las personas cuya imagen trata de captarse, reproducirse o difundirse han de prestar su consentimiento, tiene una salvedad clara en el caso de las personas públicas.

De esta forma, la Ley aclara -y quien dice «aclara» dice enturbia o confunde -que no considera intromisión ilegítima la captación y el uso posterior de imágenes de personajes públicos, cuando la fotografía sea captada durante un «acto público o en lugar abierto al público» ${ }^{105}$. Como puede imaginarse, el problema viene a la hora de determinar qué abarcan estos dos presupuestos.

\footnotetext{
${ }^{100}$ Así, como indica la STS de 3 de noviembre de I988, no puede considerarse accesoria la imagen de un hombre desnudo tomada a corta distancia. Y por muy fugaces que sean las imágenes en el vídeo no han de ser «objeto principal» del mismo, puesto que, en ese caso, no serían accesorias (STS de 23 de mayo de 2003).

${ }^{\text {Ior }}$ STS 6I9/2005, de I5 de julio, rec. 3II8/200I, siempre que, aunque fugaces, no sean las imágenes del vídeo «objeto principal» del mismo (STS de 23 de mayo de 2003).

${ }^{102}$ Vid. STS24I/2003, de I4 de marzo, rec. 2323/1997. Y ello, además, porque formar parte del cuerpo de policía te convierte en un «personaje público».

${ }^{103}$ STS 6I9/2005, de I5 de julio, rec. 3II8/200I.

${ }^{104}$ Art. 2.I LO I/I982.

${ }^{105}$ El art. 8.2.a) establece que «En particular, el derecho a la propia imagen no impedirá: su captación, reproducción o publicación por cualquier medio cuando se trate de personas que ejerzan un cargo público o una profesión de notoriedad o proyección pública y la imagen se capte durante un acto público o en lugares abiertos al público».
} 
La Ley, en una absoluta inconcreción, consideró que son personajes públicos aquellos que ejercen un cargo público o profesión de notoriedad o proyección pública. Pero, ¿qué hay de aquellos que, sin concurrir en ellos estos elementos, son populares? ¿No entran en esta excepción? Y lo que es más, ¿gozará de la misma protección jurídica un personaje público que airea su vida en los medios de comunicación o comercializa con su imagen para publicidad que otro personaje público, conocido por su trabajo o proyección pública, pero que nunca se ha lucrado con ella?

No contaba la norma con que la popularidad es algo meramente fáctico que consiste en el conocimiento y el interés que suscita una persona entre el común de la gente en un ámbito más o menos amplio y que no siempre se justifica en un cargo público o una profesión de notoriedad. Tuvimos que esperar nada menos que dieciocho años para que el Tribunal Constitucional aclarara qué había de entenderse por «personaje público» ${ }^{\text {106 }}$. El Tribunal sentó que englobaba a aquella persona que tuviera atribuida la administración del Poder Público y aquellos otros que alcanzan cierta publicidad por la actividad profesional que desarrolla o bien, y aquí está lo importante, por difundir habitualmente hechos y acontecimientos de su vida privada ${ }^{\mathrm{rot}}$. Por otro lado, sin que pueda extenderse nunca notoriedad a los hijos menores ${ }^{\text {108 }}$.

Aclarada en un sentido más amplio, pero más racional, la raquítica literalidad del precepto en lo referente al ámbito subjetivo, resta concretar el alcance de la excepción.

Es evidente que esta nota de popularidad, entendida como conocimiento general de un sujeto, implica necesariamente un sacrificio en el alcance de la reserva que sobre la imagen y datos de la vida privada puede aspirar a mantener una persona con notoriedad. Pero, una cosa es la limitación del derecho, otra bien distinta, la absoluta negación del mismo. La aplicación literal del art. 8.2.a) significaría y, de hecho lamentablemente lo significó en una época para el Tribunal Supremo (atiéndase por ejemplo a las sentencias del Caso Lydia Bosh o en el Caso Alcocer ${ }^{109}$ ), que toda información sobre hechos que les conciernan, guarden o no relación con su actividad profesional, cuenten o no con su conformidad goza de especial protección, lo que, además de ser injusto, es de todo punto inconstitucional ${ }^{\text {IIO }}$.

\footnotetext{
${ }^{106}$ Vid. STC II2/2000, de 5 de mayo, rec. 4207/1996.

${ }^{107}$ Nuestra jurisprudencia no distingue entre personajes públicos absolutos y relativos como en Alemania, pero cabe entender que bajo el concepto de figura pública que comprende tanto aquellas personas que por el ejercicio de funciones o cargos públicos reciben la condición de públicas (personajes públicos absolutos), como aquellas otras que por su actividad profesional o por difundir de forma habitual elementos de su vida privada, poseen tal notoriedad (personajes públicos relativos).

${ }^{108}$ Debe respetarse el principio general de que la notoriedad pública como factor modulador de la intensidad de los derechos al honor, la intimidad y la propia imagen, solamente es aplicable de los progenitores que estén revestidos de tal nota, si que quepa transferir tales efectos a sus hijos menores. STS 782/2004, de I2 de julio, rec. 3I/2000.

${ }^{109}$ Sentencias del Tribunal Supremo 242/2000, de 24 de abril, rec. 2196/1995 y de I7 de diciembre de I997, rec. 30/1994, respectivamente, en las que se llegó a manifestar que, en los personajes públicos, el derecho al honor disminuye, la intimidad se diluye y el derecho a la propia imagen se excluye.

${ }^{\text {IIo }}$ En estos términos se expresa CAllejo CARrión, S., «Los desnudos, el Tribunal Supremo y el derecho a la propia imagen», Diario La Ley, N 7I72, 2009, pág. 5 (fecha de consulta I2/12/20I5).
} 
A mi parecer, este «totum revolutum» ha tenido causa en un error de base desde los tribunales, especialmente del Tribunal Supremo, que han hecho una lectura, ya no sólo literal, sino aislada, del art. 8.2.a). «Al rescate» ha tenido que venir el TC en su especial condición de garante de los derechos fundamentales, para precisar -que no «innovar» como han dicho algunos ${ }^{\text {III }}$ - la exigencia de la aplicación del requisito previo del «interés público o formativo», corrigiendo el exacerbado criterio de un Tribunal Supremo más favorable al art. 20 CE. Una corrección que, como una suerte de contrapeso a la generalización de las TICs, ha provocado una auténtica expansión de los derechos del art. I8 CE. Así, junto a ese elemento subjetivo del carácter público de la persona afectada, es exigible el elemento objetivo de que los hechos constitutivos de la información tengan relevancia pública ${ }^{\text {Ir2 }}$.

Sin embargo, no se ha aprendido la lección el Tribunal Supremo, que ha buscado la manera de eludir la doctrina constitucional, arguyendo, en unos casos, que la misma se refiere únicamente al derecho a la intimidad ${ }^{\mathrm{Ir}}$, llegando incluso, en otras ocasiones a defender la legítima protección de un «interés frívolo» ${ }^{\text {Ir4 }}$. Desde este ángulo, no parece que puedan tener relevancia pública, más allá de ese interés frívolo, las fotografías tomadas de las vacaciones en de un conocido sujeto en el mundo de las finanzas ${ }^{\mathrm{II}}$, de una princesa europea $^{\mathrm{r1} 6}$, o las fotografías en la playa de un conocido empresario español ${ }^{117}$, incluso en un

"'Iengo que disentir de la opinión de autores como De LA IgLESIA CHAMARRo que considera que el Tribunal Constitucional incluye un criterio nuevo no previsto para abordar la ponderación constitucional. DE LA IGLESIA ChAmARro I., «El derecho a la propia imagen de los personajes públicos. Algunas consideraciones a propósito de la SSTC i39/200I (Caso Cortina) y 83/2002 (Caso Alcócer) », Revista española de Derecho Constitucional, $N^{\circ}$ 67, 2003, pág. 3II, disponible en dialnet.unirioja.es (fecha de consulta II/12/20I5).

Ya en la tramitación de esta ley se puso de manifiesto esta circunstancia cuando Pons IrAZAZABAL dijo que «(...) porque naturalmente, el problema de protección de la vida privada se plantea, en general, con aquellas personas que tienen una vida pública, como por ejemplo los artistas, que tienen derecho como todas las otras personas físicas a la protección de su vida privada y que sólo ellas tienen derecho a fijar los límites de los que puede ser publicado sobre su vida íntima». DSC núm. 206, de Io de diciembre de I98I, pág. I2302.

${ }^{112}$ Así lo expresaba la STC i97/I99I, en su FJ4. En una sentencia más reciente, de io de febrero de 20I4, sostiene la exigencia de interés informativo en la publicación para hacer aplicación de la excepción establecida en el art. 8.2.a). Señala que no se informa de aspectos relacionados con la actividad profesional de la actora, sino de lo que hace en su tiempo libre (actividades de carácter puramente privado, tomando el sol y paseando con amigas en la playa) que no satisfacen objetivamente la finalidad de la formación de la opinión pública. Pone, además, de manifiesto la irrelevancia de la proyección pública del personaje o de la circunstancia de que las imágenes se captasen en un lugar público, señalando que «dichas circunstancias, por sí solas, no justifican la difusión de cualquier imagen, pues no cabe privar incondicionalmente a la persona de la capacidad de decidir sobre qué aspectos de ella desea preservar de la difusión pública».

${ }^{113}$ Por ejemplo, ver la STS 435/20II, rec. 398/2009 $\left(\mathrm{FJ} 3^{\circ}\right)$, contrariando su propio criterio en la sentencia $332 / 2010$, de 24 de mayo, rec. 540/2007 $\left(\mathrm{FJ}_{2}^{\circ}\right)$, en la que considera predicable, igualmente, esta doctrina al derecho a la propia imagen.

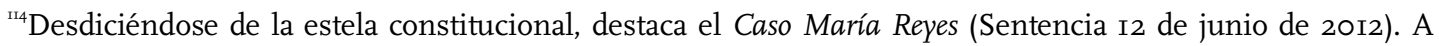
raíz de la publicación en la Revista Interviú de unas fotos en las que la modelo aparecía en top less mientras disfrutaba de una jornada habitual y cotidiana en la playa de Ibiza, el Tribunal considera que hay interés en las fotografías captadas, puesto que considera el interés frívolo, plenamente admitido por los usos sociales también debe ser tenido en cuenta en los conflictos que se planteen entre los derechos de comunicación social y derecho a la propia imagen. Así lo entiende, SuÁreZ Espino, M. L., «Qué protege el derecho fundamental a la propia imagen », Diario La Ley, N779I, 220I2, pág. 9, disponible en laleydigital.laley.es, (fecha de consulta:II/I2/20I5).

${ }^{115}$ En la Sentencia 139/200I, relativa al conocido Caso Cortina, para el Tribunal Constitucional la notoriedad pública de un sujeto conocido en el mundo de las finanzas no supone una exclusión absoluta del derecho a mantener libres de conocimiento ajeno los aspectos concernientes a sus relaciones afectivas.

${ }^{\text {r16 }}$ El Caso Carolina de Mónaco es un icono de la jurisprudencia en este asunto del Tribunal Europeo de 
lugar abierto al público. No tienen relevancia pública. No, al menos, una relevancia protegible que contribuya a generar una opinión pública responsable sino, si acaso, la mera satisfacción la curiosidad ajena.

Y a partir de aquí llegamos a lo que, para mí, constituye la clave hermenéutica del precepto: la consideración irrebatible de que un personaje público sigue siendo persona. Abarcando, por tanto, una dimensión pública y conservando, ya sea de mayor o menor amplitud, siempre, una privada que no presenta interés público -protegible- alguno. Hasta el punto de que, en defecto de ese interés, la proyección pública del personaje y el lugar abierto al público que cita el precepto, llegan a ser irrelevantes. De tal manera que, sólo cuando se trata de un personaje público, la imagen tenga relevancia pública y, además, se haya captado en un lugar público, no existirá intromisión en los derechos del art. I8.

Y a esto último nos vamos a referir ahora: «Lugar abierto al público». Parece obvio lo que se ha de entender por lugar abierto al público: todo aquel al cual una persona pueda tener acceso en un momento determinado ${ }^{\text {I18 }}$. Sin embargo, si lo analizamos más detenidamente enseguida nos damos cuenta de lo incoherente de esta interpretación. ¿Es que sólo en el domicilio podemos hacer valer los derechos del art. I8? Evidentemente no. Se hace necesaria una interpretación finalista, además de coherente con la dimensión dual de los personajes públicos, que evita, por ejemplo, considerar lugar público un probador de ropa, aunque está ubicado en un establecimiento comercial abierto al público ${ }^{\text {Ing }}$; una reserva federal en Keynia; o un lugar apartado en una playa ${ }^{\text {r2o }}$. La razón tiene que ver con que no queremos quitarnos la ropa en público, no queremos veranear en pleno centro de una ciudad y no queremos hacer top-less en una playa concurrida. Queremos mantener nuestra privacidad. Detrás, en definitiva, subyace el consentimiento, como elemento volitivo en el sentido de limitar nuestro espacio personal.

Derechos Humanos. STEDH, de 24 de junio de 2004 As. Von Hannover contra Alemania, disponible en http://www.worldlii.org/eu/cases/ECHR/2004/294.html (fecha de consulta: 2/12/20I5).

${ }^{117}$ STC 83/2002, Caso Alcócer.

${ }^{\text {ri }}$ La STS II44/2008, de 28 de noviembre, rec. 29/2004, determina que ha de entenderse que lugar abierto al público es aquel que resulte de uso normal por una generalidad de personas que accedan a él fuera del ámbito estricto de la vida privada.

${ }^{119}$ STS 28I/200I, de 22 de marzo, rec. 7I6/1996 $\mathrm{FJ}^{\circ} 2$.

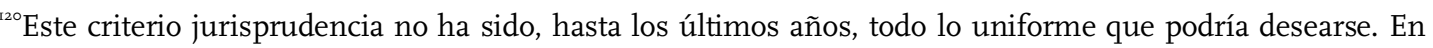
un criterio más acertado, en el Caso de Silvia Munt, resuelto por la STS de 29 de marzo de I988, se considera que existe intromisión ilegítima porque la actriz había buscado un lugar recóndito, lo que pone de manifiesto que había tomado una serie de precauciones para evitar que su imagen fuera captada con facilidad. Asimismo, la Sentencia de 27 de septiembre de 1993 establece que «aunque la playa sea un lugar abierto al público no es incomprensible con que haya lugares apartados que permitan la intimidad», Otros pronunciamientos, como la STS de 28 de noviembre de 2008 han llegado a decir que «Una playa salvo que sea de nudistas, circunstancia que por su destino le confiere cierta privacidad digna de protección, nunca puede ser considerada un lugar privado por más que su ubicación tenga difícil acceso y sea poco frecuentada, pues estas circunstancias no son condicionantes y determinantes de la intimidad personal, de manera que en lugares públicos cualquier personaje público está expuesto a que su imagen pueda ser tomada y luego reproducida en cualquier medio informativos». 


\section{VI.2.3. Personas fallecidas}

Es dramáticamente habitual la publicación de fotografías de personas ya fallecidos, incluso, de imágenes representativas del momento del fallecimiento o del cuerpo sin vida de un fallecido. Valga de ejemplo la difusión mediática de los fallecimientos de Muamar Gadafi o Sadam Husein o de personas fallecidas como ha ocurrido en el caso Asunta ${ }^{\text {I2r }}$. Efectivamente, la muerte es notica, pero al margen de ese «pulso» entre la lesión de la vida íntima con la difusión de imágenes sobrecogedoras innecesarias y el interés general o público de las mismas que ampara el derecho a la información, la problemática en estos casos radica en «la defensa de la personalidad pretérita ${ }^{\mathrm{I22}}$.

Si algo tenemos claro a estas alturas que es los derechos fundamentales del art. I8 CE son derechos personalísimos en tanto se derivan de la dignidad de la persona, por lo que están ligados a la existencia misma del individuo y resultan intransmisibles. Así las cosas, una vez fallecido el titular de estos derechos y, por tanto, extinguida la personalidad ${ }^{123}$, lógicamente, desaparecerá el objeto de protección, sin que puede corresponder, por tanto, su tutela post mortem a los parientes más próximos al difunto. Es claro que, si la imagen es una prolongación de la personalidad, a los que no están entre nosotros no se les puede ofender por intromisiones a lo que en su vida era su derecho al honor, a la intimidad o a la propia imagen, ya nadie puede causarles perjuicio. Pero la memoria difunti sobrevive y subsiste a la personalidad. Quizá la pregunta clave aquí consista en preguntarse a quién y a qué derecho se causa el daño.

No cabe duda de que aquello que le ocurre a nuestros padres, cónyuges o hijos, normalmente y dentro de las pautas de la sociedad, incide directamente en la esfera de nuestra personalidad ${ }^{\mathrm{r} 24}$. ¿Pero qué derecho se está protegiendo? Un derecho propio y no ajeno del fallecido: el derecho a la intimidad de los familiares ${ }^{\mathrm{T} 25}$. Y es que «Los muertos viven también en la memoria de los que viven y que forma parte del deseo de perdurabilidad de todo ser humano dejar recuerdo de su existencia (...) ${ }^{126}$. La intimidad, por tanto, se extiende no sólo a los aspectos de la vida propia personal, sino también a determinados aspectos de otras personas con las que se guarde una especial y estrecha vinculación familiar, aspectos que inciden en la propia esfera de la personalidad del individuo que los derechos del art. I8 CE protegen ${ }^{\text {I27 }}$.

\footnotetext{
${ }^{\text {121 }}$ Pouso TORRES, E., «Límites de la libertad de expresión en el respeto a la intimidad: estudios de caso en el tratamiento de imágenes», Estudios sobre el Mensaje Periodístico, № I8, 20I2, págs. 72I- 728.

${ }^{122}$ La Exposición de Motivos de la Ley I/I982 refleja esta realidad cuando afirma que « (...) la muerte del sujeto de derecho extingue los derechos de la personalidad (...)».

${ }^{123}$ Como dispone el art. 32 del Cc, la personalidad civil se extingue por la muerte de las personas.

${ }^{124}$ V.gr. SAP de Cáceres 138/2004, de 26 de abril, rec. I65/2004. Los demandantes denunciaron la intromisión en los tres derechos del art. I8 por la publicación del carácter seropositivo del fallecido, reconociéndose exclusivamente la lesión del derecho a la intimidad. A este respecto ver también la STC I97/I99I, de I7 de octubre, Rec 492/i989.

${ }^{125}$ Así lo aseveró la STC 23I/ı988, de 2 de diciembre, rec. I247/I986.

${ }^{126}$ Diario de Sesiones del Congreso (DSC), de io de diciembre de I98I, n 206, , pág. I2.300,

${ }^{127} \mathrm{El}$ art. 4 de la LO I/I982 se encarga de determinar a quién corresponde la tutela post mortem, señalando
} 
Ahora bien, una vez publicadas estas imágenes en las SRS que pueden permanecer en el muro del fallecido a través de mecanismos como el «etiquetado», los familiares habrán de proceder a la desactivación de la cuenta para borrar la «herencia digital», esa personalidad paralela virtual del fallecido ${ }^{\mathrm{I} 28}$.

\section{VI.2.4. Menores}

Si las redes tienen unos usuarios protagonistas, esos son los menores. Ya sea porque el propio menor cuelgue alguna fotografía en su perfil de una red social, ya porque otros lo hagan. En este ámbito, la eficacia del consentimiento del menor de edad cede, necesariamente, ante su especial vulnerabilidad y, con ella, la regla general del consentimiento también encuentra aquí una excepción ${ }^{\text {129 }}$.

La primera parada obligatoria hemos de realizarla en la LO I/I983, en la que se anuda la eficacia del consentimiento a lo que se ha venido a llamar «condiciones de madurez» suficientes, de acuerdo con la legislación civil ${ }^{130}$. Una remisión que, sin embargo, se antoja muy poco útil, pues el Código civil no incluye regla alguna que establezca cuando un menor es suficientemente maduro para prestar su consentimiento en materia de derechos de la personalidad ${ }^{131}$.

Cuando éstas no concurran, el consentimiento habrá de otorgarse mediante escrito por su representante legal, quien estará obligado a poner en conocimiento previo del Ministerio fiscal el consentimiento y si en el plazo de ocho días el Ministerio Fiscal se opusiere resolverá el Juez. Con todo, puede imaginarse que, en la práctica, cada vez que algún usuario de una SRS quiera publicar una foto en la que aparezca otro usuario menor de edad sin esas «condiciones de madurez» no lo va a notificar al Ministerio Fiscal ni mucho menos van a esperar a que resuelva un Juez. Y es aquí, donde la LO I/1996 de protección al menor, aun suponiendo una contravención de los principios generales que obligan a interpretar restrictivamente las limitaciones de la capacidad de obrar y un cuestionamiento de la representación legal, acotó la imposibilidad fáctica del control previo

que serán el cónyuge, los descendientes, ascendientes y hermanos en defecto de quien se haya designado en testamento

\footnotetext{
${ }^{128}$ Estas cuestiones ya se regulan en los términos de uso de algunas redes sociales, como Twitter o Facebook. Enlaces para cancelación de las cuentas de fallecidos disponibles en:

https://support.twitter.com/articles/20169203;

https://www.facebook.com/note.php?note_id=IOI5033443I075600 (fecha de consulta: 2I/I2/20I5).

${ }^{129}$ RUEDA MARTín, M, «La relevancia penal del consentimiento del menor de edad en relación con los delitos contra la intimidad y la propia imagen», InDret, $\mathrm{N}^{\circ} 4,2013$, págs. 23 y ss., disponible en:

http://www.raco.cat/index.php/InDret/article/viewFile/270I85/35776I (consulta 20/I2720I5).

${ }^{130} \mathrm{El}$ art. 3 de la LO I/I982 establece que «I. El consentimiento de los menores e incapaces deberá prestarse por ellos mismos si sus condiciones de madurez lo permiten, de acuerdo con la legislación civil. 2. En los restantes casos, el consentimiento habrá de otorgarse mediante escrito por su representante legal, quien estará obligado a poner en conocimiento previo del Ministerio Fiscal el consentimiento proyectado. Si en el plazo de ocho días el Ministerio Fiscal se opusiere, resolverá el Juez».
}

${ }^{13} \mathrm{Al}$ contrario, el art. I62.I.I ${ }^{\circ}$ se limita a disponer que se exceptúan de la representación legal «Los actos relativos a los derechos de la personalidad del hijo, de acuerdo con las Leyes y con sus condiciones de madurez, pueda realizar por sí mismo». 
del Ministerio Fiscal al que obliga el art. 3.2 LO I/I982 $2^{\mathrm{I32}}$. En una línea paternalista, posteriormente limitada por interpretación de la Fiscalía General del Estado ${ }^{\mathrm{I} 33}$, amplía el concepto de intromisión ilegítima a la difusión de cualesquiera datos o imágenes de menores en los que los medios de comunicación afecten negativamente al interés del menor $^{\mathrm{I} 34}$.

Más clara resulta la normativa reguladora del derecho a la protección de datos ${ }^{135}$, en el art. I3 del Reglamento de desarrollo de la LOPD, según el cual para procederse al tratamiento de los datos de los menores de catorce años se requerirá el consentimiento de los padres o tutores ${ }^{\mathrm{I3} 6}$.

En cualquier caso, si la LO I/1996 nos obliga a prescindir del consentimiento cuando afecte negativamente, no lo hace en el resto de los casos, en los que seguimos con el problema inicial de indeterminación de capacidad del menor para prestar válidamente consentimiento. Cabe plantearnos en este punto si no sería aconsejable abandonar este standard o criterio subjetivo de madurez y, con él, la inseguridad jurídica y costes que plantea, por una regla objetiva basada en la edad ${ }^{137}$. Más, si tenemos en cuenta que, siendo la imagen un dato personal y estableciendo la normativa al respecto como edad válida para consentir la de catorce años, podemos llegar al absurdo de que la difusión de la misma imagen del mismo menor, suponga la lesión del derecho a la propia imagen y no a la protección de datos o, al revés, que careciendo de un parámetro objetivo para determinar las «condiciones de madurez» podemos estar en el sinsentido de que la difusión de una misma imagen lesione el derecho a la protección de datos y no los derechos al honor, intimidad y propia imagen ${ }^{\mathrm{r} 38}$.

\footnotetext{
${ }^{132}$ Dictada con la voluntad declarada de «reforzar los mecanismos de garantía previstos en la LO I/I982 y de proteger al menor que puede ser objeto de manipulación incluso por sus representantes legales». Exposición de Motivos, apartado $2^{\circ}$.

${ }^{133}$ En este sentido, la Instrucción 2/2006 de la Fiscalía General del Estado, sobre el Fiscal y la protección del derecho al honor, intimidad y propia imagen de los menores, pone mesura al sobreproteccionismo de la Ley del Menor. Entre otras cosas, matiza que, si se trata de una información neutra o positiva, las imágenes pueden publicarse sin pixelar, pero en este caso con permiso de los padres.

${ }^{134} \mathrm{El}$ art. 4.3 LO I/1996 establece que «se considera intromisión ilegítima en el derecho al honor, a la intimidad personal y familiar y a la propia imagen del menor, cualquier utilización de su imagen o su nombre en los medios de comunicación que pueda implicar menoscabo de su honra o reputación, o que sea contraria a sus intereses incluso si consta el consentimiento del menor o de sus representantes legales».

${ }^{135}$ El nuevo Reglamento de Protección de Datos prevé un régimen diferente en cuanto al consentimiento de menores.

${ }^{136}$ En este ámbito, son ya numerosas las sanciones que viene imponiendo la AEPD respecto a la publicación de los centros educativos sin requerir a través de los formularios oportunos consentimiento de los padres. Ver Informe oI94/2009 de la AEPD, relativo a las fotos de un menor publicadas en la página web del colegio.

${ }^{137}$ En este sentido opina GUINEA FERNÁNDEZ, quien opta por la edad de I4 años, aunque advierte que no es probable que esto llegue a suceder en un futuro cercano, porque se ha optado por analizar si el menor reúne las necesarias condiciones de madurez caso por caso. GuinEA FERnÁndEZ, D.R., «Autonomía de la voluntad: ejercicio del derecho al honor, a la intimidad y a la propia imagen», Diario La Ley, N 5, 20I5, pág. II (fecha de consulta $20 / 10 / 2015)$.

${ }^{138} \mathrm{De}$ acuerdo con el art. I3 de la LO I5/I999, de I3 de diciembre (RLOPD), que regula el consentimiento para el tratamiento de datos de menores de edad, es legítimo el «tratamiento de los datos de los mayores de edad de I4 años con su consentimiento, salvo en aquellos casos en los que la Ley exija para su prestación la asistencia de los titulares de la patria potestad o tutela». Así lo aclara, por otro lado, el Informe 2000-০oo de la Agencia.
} 
En todo lo que llevamos dicho hasta aquí, advertimos un pequeño error en el planteamiento. Estas previsiones podrían quedar en el aire si tenemos en cuenta que algunas de las redes sociales con mayor presencia en España radican en Estados Unidos, un ordenamiento en el que el derecho de «privacidad» dista mucho del nuestro ${ }^{139}$. Por ello, hemos de felicitarnos por algunos avances como el que ha llevado a Facebook a elevar la edad para acceder a sus servicios a catorce años y acomodarla a las normas española ${ }^{140}$ o por las iniciativas relativas a que los perfiles privados de los usuarios menores de dieciocho años no puedan indexarse en los buscadores ${ }^{\mathrm{I} 4 \mathrm{r}}$, o el que han significado el establecimiento de protocolos o controles de verificación de edad. De todos los compromisos, éste último es el más difícil de cumplir, pues esta exigencia la plantea el legislador sin tener en cuenta que, a día de hoy, no existen mecanismos tecnológicos que lo permitan ${ }^{\mathrm{I} 42}$.

Finalmente, debemos señalar que, asistimos en este punto a un problema que no nos encontramos en otros casos y que está relacionado con la publicación de imágenes de menores por parte de uno de los progenitores sin el consentimiento del otro, hecho notablemente frecuente en las RSI. El problema surge cuando uno de los progenitores, estén o no separados o divorciados, se opone a su publicación. Aquí hay una laguna legal pues no se ha determinado si es una decisión ordinaria, que no necesita del consentimiento de ambos padres, o una decisión de las que están dentro de la patria potestad y que precisa el acuerdo de ambos. De momento, la jurisprudencia viene entendiendo que se ha de solicitar previamente el consentimiento del otro progenitor, pues ambos son titulares de la patria potestad y, en su defecto, autorización judicial ${ }^{143}$.

\section{VI.2.5.Personas jurídicas}

Por lo que respecta a las personas jurídicas, a la vista del tenor literal en el que,

\footnotetext{
${ }^{139}$ Herrán Ortiz, A. I., «Las redes sociales digitales:¿hacia una nueva configuración de los derecho fundamentales en Internet», Revista Vasca de Administración Pública, № 87, 20IO, págs. 543. Ver también, SLOVE, J. D., HARTZOG, W., «The FTC and the new common law of privacy », Columbia Law Review, N II4, 20I3, págs. 583-676, disponible en http://poseidonor.ssrn.com. (fecha de consulta: го/ог/20I6).

${ }^{140}$ Este requerimiento fue aceptado por Facebook e introducido en sus políticas de privacidad para los registros en España gracias a una petición de la AEPD. Ver nota de prensa del I8 de febrero de 2010 , disponible en: http://www.agpd.es/portalwebAGPD/revista_prensa/revista_prensa/20Io/notas_prensa/common/febrero/i8o2 Io_Facebook_adecua_legislacion_es_edad_min_usuarios.pdf (fecha de consulta Io/oI/20I6).

${ }^{141}$ De acuerdo al Estudio de la Comisión Europea de 2I de junio de 20II, entonces, sólo dos redes sociales (Bebo y MySpace), tenían unas configuraciones por defecto que hacían inaccesibles los perfiles de los menores solamente a su lista de contactos aprobados. Disponible en: http://europa.eu/rapid/press-release_IP-II762_es.htm?locale=en (fecha de consulta: Iо/ог/2016).

${ }^{142}$ Tuenti, una de las redes más proteccionistas, es una de los pocas que cuenta con un control restrictivo de acceso, exigiendo copia del DNI al usuario registrado cuando presume que se trata de un menor de I4 años. Si han transcurrido 92 horas de la solicitud y el requerimiento no es satisfecho, el PSRS procede al cierre de la cuenta. Al poco tiempo de haberse implantado esta medida, el PSRS había cerrado casi 35.000 cuentas. MARTOS DíAZ, N., «Políticas de privacidad, redes sociales y protección de datos. El problema de verificación de la edad» en Rallo Lombarte, A., Martínez Martínez, R., Derecho y..., op. cit., págs.. I45-i6I.

${ }^{143}$ Así lo han establecido, recientemente, la SAP de Barcelona 265/20I5, de 22 de abril, rec. I83/20I4 O SAP de Pontevedra 208/20I5, de 4 de junio rec. 223/20I5. Se ha de añadir que el progenitor que no haya prestado su consentimiento puede solicitar al Juez la retirada de las imágenes, lo que también se puede hacer iniciado un procedimiento de jurisdicción voluntaria al amparo del art. 156 del Código Civil.
} 
constitucionalmente, se ha definido cada uno de los derechos de la personalidad, es claro que no son titulares de los derechos reconocidos en el art. i8 de la Constitución que, por su naturaleza, sólo corresponden a las personas físicas ${ }^{\mathrm{I} 44}$.

Sin embargo, desde antiguo, ya había sentencias que, en una consideración dual, reconocían que las personas jurídicas «podían sufrir ataques a la buena fama» ${ }^{\mathrm{I} 5}$. Efectivamente, tales entidades son sujetos titulares de bienes jurídicos como el prestigio o la fama, otra cuestión era determinar que éstos se pudieran equiparar al derecho al honor. Conviene recordar en este punto, que el derecho al honor tiene una consideración dual, subjetiva o interna y objetiva o externa. Esta segunda, desligada de la dignidad de la persona que es intrínseca a la primera, hace referencia a la consideración que los demás pueden tener del sujeto, la valoración o apreciaciones del mismo. Es, precisamente, la consideración del elemento externo en sí lo que ha propiciado el reconocimiento del derecho al honor de las personas jurídicas, pues si bien las mismas se ven desprovistas de la vertiente interna por su propia naturaleza, sin embargo, sí se ven afectadas de forma directa por conceptos como el prestigio ${ }^{\mathrm{T} 46}$.

Sin embargo, un camino de vacilaciones, retrasó que el reconocimiento expreso de la titularidad del derecho al honor de las personas jurídicas hasta I995, cuando se reconoce que deberán ser titulares de aquellos derechos fundamentales que sean acordes con la finalidad que persiguen ${ }^{\mathrm{I} 47}$. Es precisamente en este ámbito en el que entra en juego el derecho fundamental al honor y ello porque el desmerecimiento de la consideración ajena sufrida por determinada persona jurídica conllevará, sin duda, la imposibilidad de que ésta pueda desarrollar libremente sus actividades encaminadas a la consecución de sus fines. Por tanto, ahora, una empresa aérea, un partido político, incluso la SGAE pueden suscitar una demanda de intromisión a su honor por contenidos vertidos en Internet ${ }^{\mathrm{t} 4}$. Ahora bien, esta será la única vía de la que gocen, dado que la protección conferida por la LOPD no es aplicable a las personas jurídicas ${ }^{\mathrm{I} 9}$.

\footnotetext{
${ }^{144}$ Como se ha indicado, la complejidad de este asunto es consecuencia, fundamentalmente, de que la construcción dogmática de los derechos fundamentales se realizó en un determinado momento histórico bajo la égida del liberalismo individualista. VIDAL MARTín, T., «Derecho al honor, personas jurídicas y tribunal constitucional», InDret Revista para el Análisis del Derecho, $\mathrm{N}^{\circ}$ I, 2007, pág. I, disponible en: http://www.indret.com/pdf/397_es.pdf), (fecha de consulta 9/12/20I5).

${ }^{145}$ STS 861/1997, de 9 de octubre, rec. 861/1997, FJ $3^{\circ}$.

${ }^{{ }^{14} 6}$ Mesía de la Cerda Ballesteros, J. A., «Implicaciones del uso de internet en la protección del derecho al honor», Actualidad civil, $\mathrm{N}^{\circ} 4,2014$, págs. 42I y ss.

${ }^{147}$ Así, nuestros Tribunales ha reconocido que el derecho fundamental al honor no es patrimonio único de las personas físicas, sino que habida cuenta de su significado, ni puede ni debe excluir de su ámbito de protección a las personas jurídicas. Ver la Sentencia del Tribunal Constitucional I39/1995 de 26 de septiembre, recurso 83/I994, en la que, por primera vez, se reconoce este derecho a las personas jurídicas.

${ }^{148}$ STS 668/20I3, de 2 de diciembre, rec. 68/20I8, del caso Ryanair Limited contra Facua Consumidores en Acción; SAP de Valencia 338/20I4, de 5 de diciembre, rec. 455/20I4; y STS 742/2012 de 4 de diciembre, rec. I626/20II.

${ }^{149}$ Así lo determina la propia Ley en su art. I al establecer que tiene por objeto «garantizar y proteger, en lo que concierne al tratamiento de datos personales, las libertades públicas y derechos fundamentales de las personas físicas (...)». Esta exclusión alcanza a los profesionales que organicen su actividad bajo la forma de empresa, manteniendo bajo su ámbito de protección a los profesionales liberales. MARín GARCÍA DE LEONARDO, T., «El derecho al honor de las personas jurídicas», en VerDA y BEAMONTE, J.R., Veinticinco años de Aplicación de
} 


\section{Conclusiones}

I. Las redes sociales como arma de «doble filo». La generalización de los dispositivos de captación de imagen junto con el incremento en el uso masivo de las redes sociales como medios de difusión, ha creado un espacio idóneo para la lesión de los derechos al honor, la intimidad, la propia imagen y la protección de datos. Por ello, se ha generalizado el nacimiento de situaciones variadas y novedosas, como la difusión inconsentida de imágenes, otorgando a los viejos conflictos una nueva dimensión.

II. La Constitución «a prueba». La Constitución y la LO I/I982, como desarrollo de su art. I8, han demostrado capacidad suficiente para dar respuesta a la lesión de los derechos fundamentales y amparar las lesiones producidas por la difusión de imágenes sin consentimiento en el contexto de las redes sociales. Consecuencia lógica derivada de que la delimitación constitucional de los derechos al honor, la intimidad y la propia imagen sigue siendo válida.

III. ¿Garantías constitucionales en manos ajenas? Aunque la LO I/I982 se muestra eficaz, en muchos casos, las garantías constitucionales dependen de un ordenamiento jurídico extranjero en el que el régimen de la Constitución y la LO I/I982 no resulta aplicable. Así, el consentimiento y la forma de su prestación, «llave» para la consideración de la intromisión, quedan en manos del país donde está radicado el prestador de servicios.

IV. Implicaciones del uso de las redes sociales. Que la delimitación constitucional siga siendo válida no implica que estos derechos operen con el mismo alcance en este contexto. Las redes sociales como plataformas donde comúnmente se comparten imágenes y aspectos de la vida privada por los usuarios implican, por un lado, una reducción de la amplitud del ámbito que queda reservado a los demás. Por otro, las redes sociales como medios de comunicación social, aún en sentido amplio, pueden llegar a ser consideradas medio a través del cual se ejercite el derecho a la libertad de información. Ambos factores, que no traen causa en una deficiente configuración legal de los derechos, merman el ámbito de protección constitucional de los derechos reconocidos en el art. i8 de la Constitución.

V. Absoluta vigencia del conflicto. La confrontación entre los derechos al honor, la intimidad y la propia imagen con el derecho a la información y a la libertad de expresión no ha dejado de ser un tema de candente actualidad. Precisamente, esta vez, el debate lo ha originado la Proposición no de Ley realizada el 3 de noviembre de 2016 por el Gobierno para adaptar, en una errada técnica legislativa o con otros propósitos (dada la eficacia de la regulación vigente), la ley al desarrollo tecnológico producido desde su promulgación ${ }^{150}$.

la LO 1/1982, de 5 de mayo, de Protección Civil del Derecho al Honor, a la Intimidad Personal y Familiar, a la Intimidad Personal y Familiar y a la Propia imagen, Aranzadi, Pamplona, 2007, pág. 75 y ss.

${ }^{150}$ Disponible en:

http://www.congreso.es/public_oficiales/Li2/CONG/BOCG/D/BOCG-I2-D-43.PDF\#page=IO

(fecha de consulta: I6/ı2/20I6). 